\title{
An ENU Mutagenesis-Derived Mouse Model with a Dominant Jak1 Mutation Resembling Phenotypes of Systemic Autoimmune Disease
}

\author{
Sibylle Sabrautzki, ${ }^{\star}$ Eva Janas, ${ }^{\star \dagger}$ Bettina Lorenz-Depiereux, ${ }^{\ddagger}$ Julia Calzada-Wack, ${ }^{* \dagger}$ Juan A. Aguilar-Pimentel, ${ }^{\star \S}$ \\ Birgit Rathkolb, ${ }^{* \Phi}$ Thure Adler, ${ }^{* \|}$ Christian Cohrs, ${ }^{*}$ Wolfgang Hans, ${ }^{*}$ Susanne Diener, ${ }^{\ddagger}$ Helmut Fuchs, ${ }^{*}$ Valerie Gailus-Durner, ${ }^{*}$

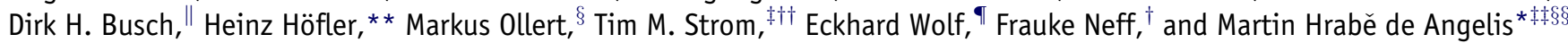

From the Institute of Experimental Genetics and the German Mouse Clinic, ${ }^{*}$ and the Institutes of Pathology, ${ }^{\dagger}$ and Human Genetics, ${ }^{\ddagger}$ Helmholtz Zentrum München, German Research Center for Environmental Health (GmbH), Neuherberg; the Department of Dermatology and Allergy am Biederstein ${ }^{\S}$ and the Institutes of Pathology and Pathological Anatomy** and Human Genetics, ${ }^{\dagger \dagger}$ Klinikum rechts der, Technical University of Munich, Munich; the Gene Center of the Ludwig-Maximilians-University Munich, ${ }^{\Uparrow}$ Munich; the Institutes for Medical Microbiology, Immunology and Hygiene ${ }^{\|}$and Experimental Genetics, ${ }^{\ddagger}$ Technical University of Munich, Munich; and the German Center for Diabetes Research (DZD), ${ }^{\S \S}$ Neuherberg, Germany

\author{
Accepted for publication \\ April 12, 2013. \\ Address correspondence to \\ Frauke Neff, M.D., Institute of \\ Pathology, Helmholtz Zentrum \\ München, German Research \\ Center for Environmental \\ Health $(\mathrm{GmbH})$, Ingolstädter \\ Landstrasse 1, 85764 Neuher- \\ berg, Germany. E-mail: frauke. \\ neff@helmholtz-muenchen.de.
}

\begin{abstract}
Within the Munich, Germany, $\mathrm{N}$-ethyl-N-nitrosourea mouse mutagenesis program, we isolated a dominant Jak1 mouse model resembling phenotypic characteristics related to autoimmune disease. Chromosomal sequencing revealed a new Jak1 (p.Ser645Pro) point mutation at the conserved serine of the pseudokinase domain, corresponding to a somatic human mutation ( $p . S e r 646 \mathrm{Phe}$ ) inducing a constitutive activation of the Janus kinase (JAK)/STAT pathway. Morphologically, all Jak1 ${ }^{5645 P+/-}$ mice showed a progressive structural deterioration of ears starting at the age of 4 months, with mononuclear cell infiltration into the dermis. Female mutant mice, in particular, developed severe skin lesions in the neck from 7 months of age. The IHC analysis of these lesions showed an activation of Stat3 downstream to Jak $1^{\mathrm{S645P}}$ and elevated tissue levels of IL-6. Histopathological analysis of liver revealed a nodular regenerative hyperplasia. In the spleen, the number of Russell bodies was doubled, correlating with significant increased levels of all immunoglobulin isotypes and anti-DNA antibodies in serum. Older mutant mice developed thrombocytopenia and altered microcytic red blood cell counts. Jak $1^{S 645 P+/-}$ mice showed phenotypes related to impaired bone metabolism as increased carboxy-terminal collagen cross-link-1 levels and alkaline phosphatase activities in plasma, hypophosphatemia, and strongly decreased bone morphometric values. Taken together, Jak1 $1^{S 645+/-}$ mice showed an increased activation of the IL-6-JAK-STAT pathway leading to a systemic lupus erythematosuslike phenotype and offering a new valuable tool to study the role of the JAK/STAT pathway in disease development. (Am J Pathol 2013, 183: 352-368; http://dx.doi.org/10.1016/j.ajpath.2013.04.027)
\end{abstract}

Inherited susceptibility to systemic autoimmune diseases derives from monogenic or polygenic reasons and may be influenced by environmental factors. Disease onset ranges from early childhood to whole lifespan, and various tissues may be involved. Linkage studies on pedigrees of patients with systemic autoimmune diseases revealed several chromosomal regions involved in disease development. ${ }^{1,2}$ Mouse models resembling systemic autoimmune phenotypes have been obtained by autoimmune disease-prone genetic backgrounds, such as MRL/ln mice on the BALB/c or the NZM2410 strain on the C57BL/6 genome, ${ }^{3,4}$ chemical treatment with tetramethylpentadecane, ${ }^{5}$ and spontaneously, ${ }^{6,7}$ chemical
$N$-ethyl- $N$-nitrosourea (ENU) mutagenesis induced ${ }^{8,9}$ or targeted mutations. ${ }^{10-12}$

The members of the Janus kinase (JAK) family play important roles in signaling downstream of cytokine receptor activation and are implicated in various physiological processes, including hematopoietic, immune, neuronal, and

Supported by the German Federal Ministry of Education and Research Nationales Genomforschungsnetz-Plus grants 01GS0850, 01GS0851, 01GS0852, and 01GS0868; Infrafrontier grant 01KX1012 (G.M.C.); OSTEOPATH grant 01EC1006B (M.H.d.A.); the German Center for Diabetes Research; and grant EU ANABONOS (LSH-2002-2.1.4-3) (M.H.d.A.)

S.S. and E.J. contributed equally to this work. 
hepatic systems. ${ }^{13}$ The JAKs are nonreceptor tyrosine kinases and consist of four mammalian members: JAK1, JAK2, JAK3, and TYK2. ${ }^{14}$ Several somatically acquired activating mutations in JAKs have been described for various hematological malignancies. ${ }^{15-17}$ However, for most of the mutations described presently, it is unclear how they contribute to disease progression. The lack of successful mouse models for mutation-activated JAK1-induced diseases hampers the understanding of disease pathological characteristics.

The genome-wide Munich ENU mouse mutagenesis program was launched, with the main focus on metabolic bone diseases. ${ }^{18}$ Within this project, we obtained the dominant $\mathrm{C} 3 \mathrm{HeB} / \mathrm{FeJ}-J a k 1^{\text {S645PMhda }}\left(\right.$ Jakl $\left.^{\text {S645P }}\right)$ mouse line carrying a new nonsynonymous point mutation within the codon of a highly conserved serine at position 645 of the pseudokinase domain of the Jakl gene. Herein, we report the morphological, histological, clinical chemical, and hematological phenotypes we found in $J a k I^{S 645 P+/-}$ mice. The identified phenotypes correlate with systemic autoimmune diseases and suggest this mutant line as a new monogenic mouse model for studies on autoimmune disease development and therapeutic strategies.

\section{Materials and Methods}

\section{ENU Mutagenesis and Mice}

We performed ENU mutagenesis and confirmation breeding of the obtained phenotypes on the inbred $\mathrm{C} 3 \mathrm{HeB} / \mathrm{FeJ}$ strain purchased originally from the Jackson Laboratory (Bar Harbor, ME), as described previously..$^{19,20}$ The mice were housed and handled according to the federal animal welfare guidelines, and the state ethics committee approved all animal studies.

Mice were kept in a 12/12-hour dark-light cycle and provided ad libitum standard chow (total pathogen-free chow 1314: calcium content, $0.9 \%$; phosphate, $0.7 \%$; and vitamin D3, $600 \mathrm{IE}$; Altromin, Lage, Germany) and water. Hygienic monitoring was performed following Federation of Laboratory Animal Science Association recommendations. ${ }^{21}$

Phenotyping was performed in the German Mouse Clinic (Münich, Germany). ${ }^{22,23}$

\section{Histological and IHC Data}

In total, 90 mice were examined at different ages $(4,8$, and 12 months). A macroscopic examination was performed in combination with histological analysis of all organs using $\mathrm{H} \& \mathrm{E}$ stain, as described previously. ${ }^{24}$ The analysis was complemented by histochemical studies for Masson's trichrome, Gomori's method for reticulin, ${ }^{25}$ and periodic acid Schiffs stain. Images for histomorphometry were taken by the slide-scanning system, NanoZoomer 2.0 HT (Hamamatsu Photonics K.K.; Hamamatsu City, Japan). The IHC was performed using the streptavidin-peroxidase method with an automated immunostainer (DiscoveryXT; Roche, Penzberg,
Germany) in paraffin-embedded tissue. After heat-induced antigen retrieval with citrate (pH 6), the following primary antibodies were used: anti-murine CD31 antibody (platelet endothelial cell adhesion molecule-1, 1:20, 5031114), purchased from Dianova (Hamburg, Germany); anti-B220 (RA3-6B2, 1:50, 550286), Mac-3 (M3/84, 1:10, 550292), and Ki-67 (B-56, 1:200, 556003) from BD PharMingen (Heidelberg, Germany); anti-CD3 (SP7, Ci597R06, ready to use) from Dako (Hamburg, Germany); anti-phosphorylatedSTAT3 [Tyr704 (D3A7) XP rabbit, 1:30, 9145] from Cell Signaling Technology (New England Biolabs GmbH, Frankfurt am Main, Germany); anti-phosphorylated interferon $\alpha / \beta$ receptor 1 (orb 5500, $1 \mathrm{mg} / \mathrm{mL}, 1: 500$ ) and antiphosphorylated-IL7 receptor $\alpha$ (orb 6212, $1 \mathrm{mg} / \mathrm{mL}, 1: 500$ ) from Biorbyt Ltd (Cambridge, UK); phosphospecific polyclonal goat anti-mouse p-gp 130 (sc-12978, 1:50) from Santa Cruz Biotechnology (Heidelberg, Germany) ${ }^{26}$; and anti-IL-6 (ab6672, 1:250) from Abcam (Cambridge, UK). Appropriate positive and negative controls, including a slide without the primary antibody, were used to confirm the specificity of the staining. Blocking against nonspecific binding was performed according to antibody information. Two pathologists (E.J. and J.C.-W.) analyzed each slide independently.

\section{Body Weight and Clinical Chemical Parameters}

Body weight was analyzed at 10 and 15 weeks of age. Blood samples were obtained from nonfasted anesthetized mice by puncture of the retro-orbital sinus, as already described. ${ }^{27}$ Plasma parameter analysis was performed using an Olympus AU400 autoanalyzer (Olympus, Hamburg, Germany) and the adapted test kits. ${ }^{28}$ Complete blood cell counts were determined in EDTA-blood samples from 4.5-month-old mice using the ABC-animal blood counter (Scil Animal Care Company, Viernheim, Germany). In addition, EDTA-blood samples of aged animals, diluted 1:5 with cell pack dilution buffer (Sysmex GmbH, Norderstedt, Germany), were analyzed using the Sysmex XT2000iV system for the complete blood cell counts, including thrombocyte size and degree of maturity, differential white blood cell counts, and reticulocyte counts.

\section{CTX-1, FGF23, and PTH ELISA Measurement}

Carboxy-terminal collagen cross-link (CTX-1) was measured in plasma using RatLaps (CTX-1) EIA [ie, enzyme linked immunosorbent assay (ELISA)] from IDS (Frankfurt am Main). Fibroblast growth factor (FGF) 23 levels were measured using a commercial full-length FGF23 ELISA Kit (Kainos Laboratories, Inc., Tokyo, Japan). For parathyroid hormone (PTH) measurement, we used an Intakt PTH mouse ELISA (Tecomedical, Bünde, Germany). Plasma samples were isolated immediately after blood withdrawal by centrifugation and were stored at $-80^{\circ} \mathrm{C}$ before biochemical analysis. Measurement of all parameters was according to the manufacturer's protocols. 


\section{Urine Collection and Analysis}

Mice were placed for 3 days in metabolic cages for single mice from Tecniplast (Hohenpeissenberg, Germany) for sampling of 48-hour urine samples after 1 day of acclimatization. Urine samples collected over 2 days were pooled and frozen. Total inorganic calcium, total inorganic phosphate $\left(\mathrm{P}_{\mathrm{i}}\right)$, and creatinine were measured by an Olympus AU400 autoanalyzer (Olympus, Hamburg, Germany).

\section{Skeletal Analysis}

Peripheral quantitative computed tomography (pQCT) analysis was performed using Stratec XCT Research SA+ (Stratec Medizintechnik GmbH, Pforzheim, Germany). The spatial resolution was set to $70 \mu \mathrm{m}$, and the distal femoral metaphysis and diaphysis of the left femur from each mouse were examined to obtain volumetric bone mineral density, content, and areas of the trabecular, cortical, and total bones. Periosteal and endosteal circumferences were also evaluated by the scanning. The reference line for the $\mathrm{CT}$ scans was set at the most distal point of the femur (knee joint space). At $3.0 \mathrm{~mm}$ proximal from the reference line, two slices were taken at $0.20-\mathrm{mm}$ intervals, and at $6.0 \mathrm{~mm}$ proximal from the reference line, one slice was taken to give characteristic cross sections of the femoral metaphysis and diaphysis, respectively.

\section{Bone Morphometry}

For bone morphometric analysis, micro-computed tomography $(\mu \mathrm{CT})$ images were obtained using a SkyScan 1172 in vivo $\mathrm{CT}$ (Bruker micro-CT N.V., Kontich, Belgium). Acquisition was performed in the $2 \mathrm{k}$-mode with a 0.5 aluminum filter, a frame averaging of 2 , a rotation step of $0.4^{\circ}$, and a resolution of $13.6 \mu \mathrm{m}$ per pixel. Three-dimensional reconstruction and visualization of images were performed using InstaRecon CBR software (InstaRecon, Inc., Champaign, IL) and CTVox version 1.1 (Bruker micro-CT N.V.). Bone histomorphometric analysis was performed with the CTAn software version 1.13 (Bruker micro-CT N.V.).

\section{Immunoglobulin Isotypes, Anti-DNA Antibodies, and}

\section{IL-6 Determinations in Serum}

The plasma levels of immunoglobulin isotypes (IgG1, IgG2a, IgG3, IgM, and IgA) were determined by using monoclonal antimouse antibodies conjugated to a microsphere-based multiplex assay (Luminex xMAP Technology; Bio-Rad, Munich) in conjunction with a Bioplex reader (Bio-Rad). Total IgE measurements were performed using sandwich ELISA technology with anti-IgE monoclonal capture and detection antibodies from BD Biosciences (Heidelberg, Germany).

ELISA plates were coated with calf thymus DNA (Sigma Aldrich Chemie, Steinheim, Germany) for both single- and double-stranded DNA antibody detection. Serum was diluted and loaded along with a positive [serum of MRL/MpJ-Fas (lpr) mice] and negative control sample. Subsequently, goat anti-mouse secondary antibody (polyvalent IgG, IgA, and IgM) (Sigma Aldrich Chemie) was added and incubated. Next, substrate was added and plates were read in a TECAN sunrise reader (Tecan Group Ltd., Maennedorf, Switzerland). For determination of the IL-6 levels in plasma, a commercial Bio-Plex murine cytokine panel suspension array system (Bio-Rad Laboratories Inc., Hercules, CA) was used. Plasma samples collected were frozen and diluted 1:4 for the measurement.

\section{Real-Time PCR Analysis}

Real-time PCR analysis was performed on RNA isolated from snap frozen ears of Jakl $1^{S 645 P+/-}(n=6)$ and $J_{a k l} I^{w t}(n=6)$ mice. Used primer sequences (Eurofins MWG Operon, Ebersberg, Germany) were 5'-TAGTCCTTCCTACCCCAATTTCC- $3^{\prime}$ (forward) and $5^{\prime}$-TTGGTCCTTAGCCACTCCTTC- $3^{\prime}$ (reverse). After homogenization, total RNA was isolated from the tissue using the RNeasy Mini kit (Qiagen $\mathrm{GmbH}$, Hilden, Germany), according to supplier's instructions. First-strand cDNA synthesis was performed using the RevertAid H Minus First Strand cDNA Synthesis Kit (Fermentas, Thermo Fisher Scientific, Waltham, MA). Real-time PCR was performed for the IL-6 gene using the SYBR Green-based detection system in an ABI Prism $7000 \mathrm{Se}$ quence Detection System (Applied Biosystems, Darmstadt, Germany). The mRNA expression levels in Jakl ${ }^{S 645 P+/-}$ mice were normalized according to the expression levels of the housekeeping gene, glyceraldehyde-3-phosphate dehydrogenase, and to the mean expression levels of the wild-type (WT) group using the $\Delta \Delta \mathrm{C}_{\mathrm{T}}$ method.

\section{Flow Cytometric Analysis of Peripheral Blood Leukocytes}

Peripheral blood underwent red blood cell lysis $\left(\mathrm{NH}_{4} \mathrm{Cl}-\right.$ Tris). The cells were incubated with Fc block (clone 2.4G2; BD Biosciences, San Diego, CA) in fluorescence-activated cell sorter (FACS) buffer (PBS, $0.5 \%$ bovine serum albumin, and $0.02 \%$ sodium azide, $\mathrm{pH} 7.45$ ) and stained with fluorescence-conjugated antibodies (BD Biosciences) and propidium iodide. Cells were acquired with an FACS LSR II High Throughput Sampler (BD Biosciences). Dead cells were eliminated on the basis of their propidium iodide signal, and events were gated for leukocytes $\left(\mathrm{CD} 45^{+}\right)$and subsequently analyzed by software-based semiautomatic analysis (FlowJo version 7.6.5; Tree Star, Inc., Ashland, OR). ${ }^{29}$ The flow cytometric analysis of leukocyte populations was based on two 10-parameter staining panels, covering markers for B cells (CD19, IgD, and B220), T cells (CD3, CD4, CD8, CD5, and $\gamma-\delta$ T-cell receptor), granulocytes (GR-1 and CD11b), natural killer cells (NKp46), and further subsets (CD44, CD62L, CD25, and Ly6C). 


\section{In Vitro Leukocyte Stimulation}

Whole blood $(100 \mu \mathrm{L})$ was incubated on a 96-well plate with $0.5 \mu \mathrm{mol} / \mathrm{L}$ phorbol 12-myristate 13-acetate (PMA) and 0.25 $\mu \mathrm{g}$ ionomycin or kept without stimulation (negative control) for 4 hours at $37^{\circ} \mathrm{C}$. For flow cytometric analysis, $20 \mu \mathrm{L}$ was incubated with Fc block and stained with fluorescenceconjugated antibodies and propidium iodide. Finally, erythrocyte lysis was performed. Measurements were done with a HyperCyt-Gallios system (Beckman Coulter, Inc., Brea, CA).

\section{Statistical Analysis}

Statistical differences ( $P$ values) of alterations of values between all tested affected mice and nonaffected littermates were assessed by $t$-test, giving means $\pm \mathrm{SD}$, or the MannWhitney rank-sum and/or Wilcoxon test (giving median values) using SigmaStat version 3.5 by Systat Software (Chicago, IL).

\section{Genetic Mapping}

The mutation was crossed to WT C57BL/6J mice according to dominant inheritance. DNA from tail tips of 50 phenotypically mutant and 20 WT offspring was extracted as described previously ${ }^{30}$; single-nucleotide polymorphism genotyping was performed by high-throughput matrix-assisted laser desorption/ionization time-of-flight technology (Sequenom, San Diego, CA).

\section{Chromosome Sorting and Next-Generation Sequencing}

Mouse chromosomes were sorted on an FACS Vantage flow cytometry system (BD Biosciences, Heidelberg). DNA extraction from 5,000,000 sorted chromosomes for the mutant and control strain was performed overnight at $42^{\circ} \mathrm{C}$ with $0.25 \mathrm{~mol} / \mathrm{L}$ EDTA, $10 \% \mathrm{Na}$ lauroyl sarcosine, and $50 \mu \mathrm{g}$ proteinase K. Extracted DNA was precipitated and resuspended in Tris-EDTA buffer. Paired-end libraries were constructed with the Illumina paired-end DNA sample preparation kit (Illumina, San Diego), according to manufacturer protocols, and sequenced on a Genome Analyzer IIx (Illumina), as described previously. ${ }^{31}$ We generated 182 and 224 million 76-bp paired-end reads for the mutant and control strains, respectively, of which approximately $96 \%$ and approximately $83 \%$ could be successfully aligned to the mouse reference genome $\mathrm{mm} 9$. Read mapping and variant calling were performed using the resequencing software packages BWA version 0.5.5 and SAMtools version 0.1.7 (Dice Holdings Inc., New York, NY). ${ }^{32}$ Duplicated reads were removed. Of the aligned reads, $34.6 \%$ and $18.8 \%$ mapped to the target chromosome 4 for the mutant and control strains, respectively. In total, we obtained 28 -fold coverage for the mutant and 20-fold coverage for the control strain. Sequencing of the Jakl mutation was performed by the oligonucleotides Jak1_ex14F 5'-TGGGATT-
CACTGAAGGATGG-3' and Jak1_ex14R 5'-GCGTCTGCATAGTACCCACC- $3^{\prime}$. The product size was $220 \mathrm{bp}$, and the annealing temperature was $60^{\circ} \mathrm{C}$.

\section{Results}

Inflammatory Ear and Skin Lesions in Jak1 ${ }^{\mathrm{S} 65 \mathrm{PP}+/-}$ Mice

$\mathrm{Jakl}^{\mathrm{S645P+/-}}$ mice were born with normal-appearing ears. Starting with an age of 4 months, the pinnae of both sexes shrank in a slow progression initially without apparent inflammation. With increasing age, this phenotype evolves with ear margins showing redness and thickening, as shown for a mouse at the age of 8 months (Figure 1A). Only female $J a k 1^{S 645 P+/-}$ mice developed alopecia on the neck and head, with external signs of inflammation in some animals. After the age of 8 months, redness and thickening of the tails were also observed in some female and male $\mathrm{Jakl}^{5645 \mathrm{P+} /-}$ mice. In addition, Jakl $1^{S 645 P+/-}$ mice are born with a reduced body size and showed significantly decreased body weight, as determined at the age of 10 and 15 weeks (Table 1).

Histological examination of skin lesions of the upper dorsal region and of the ears in mutant mice showed inflammatory infiltrate (predominate neutrophils) in the epidermis with hyperkeratosis and acantosis. In the dermis, thickening of the connective tissue, increased granulation tissue, and mononuclear cell infiltration were found; the latter was the most characteristic finding because it was found in $60 \%$ of the animals at the age of 8 months. The ear cartilage was primarily not affected, but was destroyed by inflammatory cells in advanced lesions. The incidence of infiltrates increased with age. Antibodies against $\mathrm{T}$ cells (CD3), B cells (B220), and macrophages (Mac-3) were selected to evaluate the cell component of the dermal infiltrate. We observed enhanced reactivity to CD3 and Mac-3 antibodies in the skin lesions of the Jakl $\mathrm{I}^{\mathrm{6} 45 \mathrm{P}+/-}$ mice compared with controls, whereas the reactivity to B220 antibody in the mutant lesions was similar to the control animals (Figure 1B). In addition, the mononuclear infiltrate of the dermis showed an increased reactivity for the proliferation marker, Ki-67, in mutant $J a k 1^{S 645 P+/-}$ mice (Supplemental Figure S1C).

\section{Activation of the IL-6-gp130-JAK-STAT Axis in Skin Lesions}

To examine the functional consequences of the $\mathrm{Jakl}^{\mathrm{S645P+/-}}$ point mutation, we performed IHC analyses on skin and ear lesions using phospho-specific antibodies for proteins of the JAK-STAT signaling pathway. The activation of JAKs is reported to result in an increased phosphorylation state of JAKs, associated receptors of three major cytokine receptor subfamilies [gp130, interferon (IFN), and $\gamma \mathrm{C}$ ], and downstream signaling proteins (eg, STATs). As shown in Figure 2, a strong phosphorylation of the Stat3 at tyrosine 705 and nuclear translocation were observed in the skin and ear lesions of $\mathrm{Jakl}^{\mathrm{S645P+/-}}$ mice compared with control mice. In skin diseases, activated STAT3 is reported to cause an autocrine 


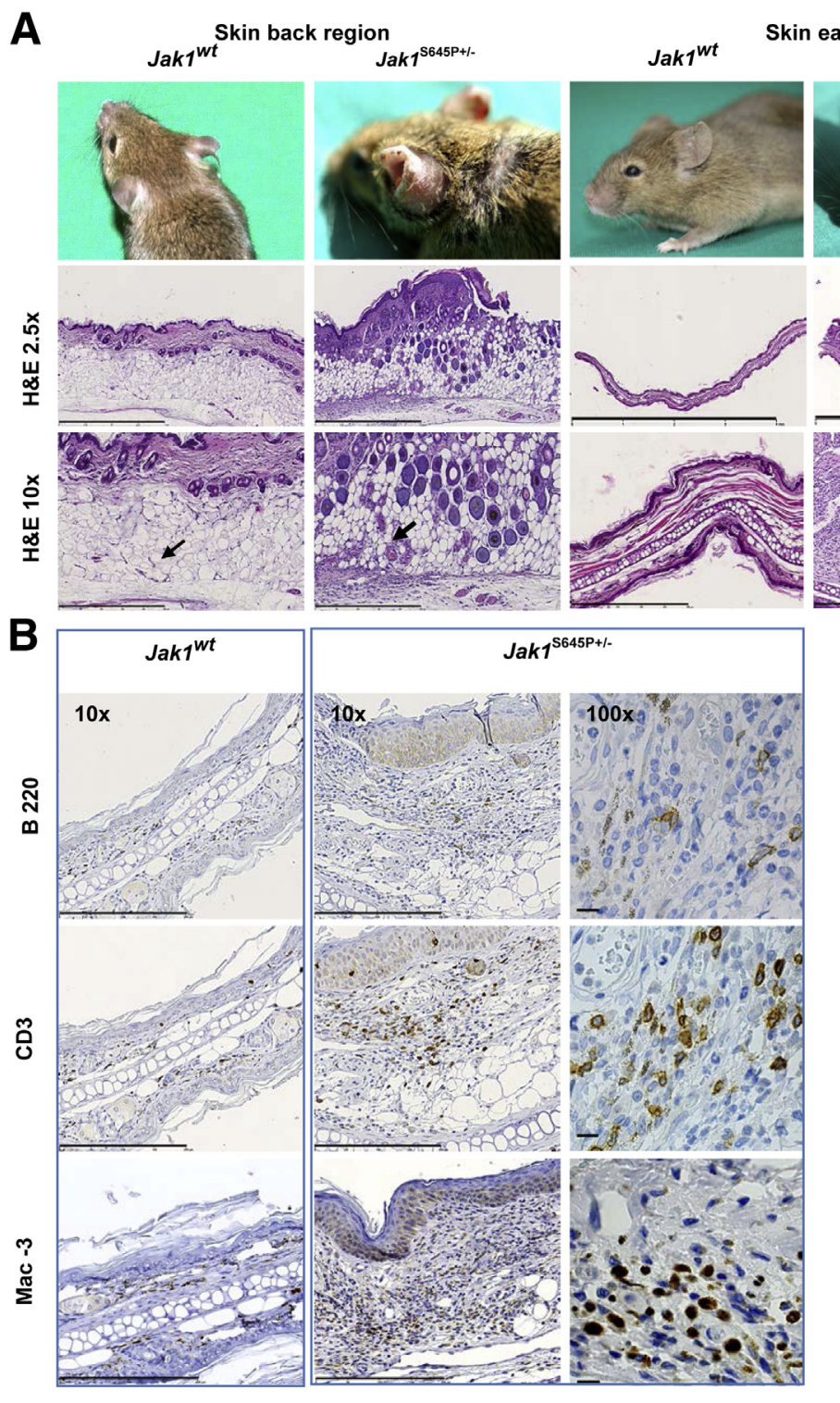

up-regulation of the IL-6-IL-6R-JAK1-pYSTAT3 axis, ${ }^{33}$ triggering an increased IL- 6 production traced to the skin. ${ }^{34}$ Herein, we also determined a strong immunostaining for IL-6 predominantly in the dermis of mutant mice. Data of locally increased IL-6 levels were correlated with a systematically increased IL-6 concentration (Figure 3).

Because JAK1 is most important for the IL-6-gp130JAK-STAT signaling, ${ }^{35}$ we focused on the phosphorylation status of gp130 by using phosphorylated-Ser782 gp130specific antibody. Serine and threonine phosphorylations of gp130, in addition to tyrosine, have been reported to be increased under stimulatory conditions. ${ }^{36,37}$ According to

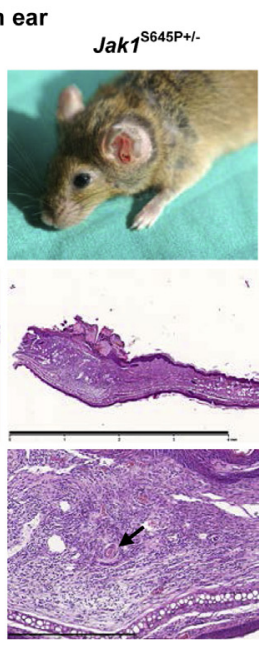

Figure 1 A: Representative skin lesions in Jak1 $1^{5645 P+/-}$ mice. Top left panel: Macroscopic findings: An 11-month-old female Jak1 $1^{\text {wt }}$ mouse with normal skin was compared with a Jak1 $1^{\text {S645P+/- }}$ mouse. Jak1 $1^{5645 P+/-}$ mice developed alopecia and a erythematous lesion on the upper dorsal region. Top right panel: Ears of a Jak1 ${ }^{w t}$ mouse compared with a Jak1 $1^{\mathrm{S} 65 \mathrm{P}+/-}$ mouse with inflammatory lesions at the age of 4 months. Bottom panels: Histological features: H\&E staining of normal and mutant mouse skin is shown. Only Jak1 $1^{\mathrm{S} 645 \mathrm{P}+/-}$ mice show a reactive proliferation of connective tissue, increased vascularization, and perivascular and diffuse dermal mononuclear cell infiltrations (arrows). The cartilage is not affected. Scale bars: $2 \mathrm{~mm} ; 200 \mu \mathrm{m}$ (respectively). B: The IHC analysis of the cellular components in the dermal infiltrate. IHC results of normal and mutant skin of ears are shown. More T cells (CD3 reactive) and macrophages (Mac-3 stained) in the skin lesions of the Jak1 $1^{\mathrm{S} 645 \mathrm{P}+/-}$ mice are detected compared with controls, whereas the number of B cells (B220 reactive) in the mutant lesions is similar to that in the control animals. Scale bars: $500 \mu \mathrm{m} ; 10 \mu \mathrm{m}$ (respectively).

Table 1 Alterations of Body Weight Changes in Jak1 $1^{\mathrm{S} 645 \mathrm{P}+/-}$ and Jak1 $1^{\text {wt }}$ Mice

\begin{tabular}{|c|c|c|c|c|c|c|}
\hline \multirow[b]{2}{*}{ Body weight (grams) } & \multicolumn{2}{|l|}{ Female } & \multirow[b]{2}{*}{$P$ value } & \multicolumn{2}{|l|}{ Male } & \multirow[b]{2}{*}{$P$ value } \\
\hline & $J a k 1^{w t}(n=22)$ & $\mathrm{Jak1}^{\mathrm{S645P+/-}}(n=21)$ & & $\overline{J a k 1^{w t}}(n=20)$ & $J a k 1^{\text {S645P+/- }}(n=14)$ & \\
\hline At 10 weeks of age & $24.0 \pm 3.8$ & $21.3 \pm 3$ & 0.004 & $28.6 \pm 1.9$ & $22.9 \pm 1.8$ & $\leq 0.001$ \\
\hline
\end{tabular}




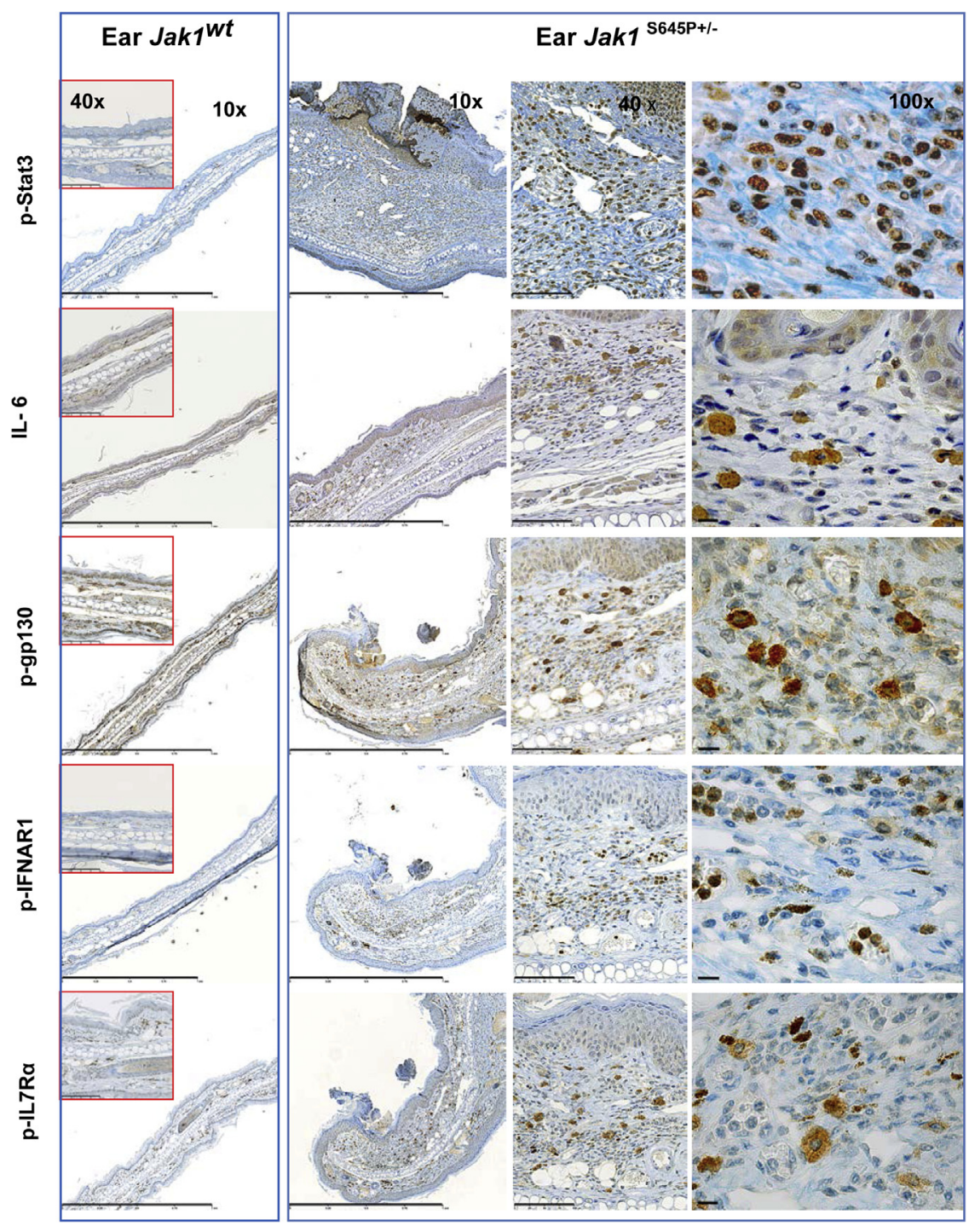

Figure 2 Up-regulation of the JAK/STAT pathway in the dermal infiltrate and increased levels of IL-6. The IHC analysis of ears revealed a strong phosphorylation of Stat3 in the skin of ear lesions of $\mathrm{Jak} 1^{5645 \mathrm{P}+/-}$ mutant compared with Jak $1^{\text {wt }}$ mice. The lesions of mutant mice showed a strong reactivity to IL-6 antibody. IHC using phospho-specific antibodies for Jak1-associated receptors of the three major cytokine receptor subfamilies (gp-130, IFN, and yC families) showed an increased phosphorylation status of all three representative receptors. Original magnifications: $\times 10, \times 40, \times 100$. Scale bars: $500 \mu \mathrm{m} ; 100 \mu \mathrm{m}$; $10 \mu \mathrm{m}$. mut, Jak1 $1^{\mathrm{S645P+/-}}$; wt, Jak1 $1^{\mathrm{wt}}$. vascularization (Figure 4). These changes were observed in $74 \%$ of mutant animals at the age of 4 months, increasing to $90 \%$ in 12-month-old mice. These changes were not associated with ascites and hepatomegaly. In the histological analysis, sinusoidal dilatation was shown by H\&E staining and by IHC using an anti-CD31 antibody (Figure 4). By using reticulin silver stain, we visualized areas composed of hyperplastic hepatocytes arranged in one- or two-cell-thick plates surrounded by atrophic hepatocytes in the adjacent parenchyma. Fibrosis was excluded with Masson's trichrome stain. Although we did not observe clear formation of small nodules, we regard these lesions as nodular regenerative hyperplasia (NRH) because they meet the diagnostic criteria, such as absence of fibrosis, sinusoidal dilatation, and alteration of the architecture of hepatic parenchyma. ${ }^{38}$ Investigating the effect of the Jakl ${ }^{S 645 P}$ mutation on downstream signaling in the liver, an increased phosphorylation of Stat 3 and its nuclear localization was determined in analogy to observation in the ear and skin lesions.
Loss of Megakaryocytes and Increase in Russell Bodies in Jak1 $1^{\mathrm{S} 645 \mathrm{P}+/-}$ Mutant Spleen

Macroscopic analysis of the spleen detected a splenomegaly for female Jakl ${ }^{S 645 P+/-}$ mice (Table 2). However, the histological analysis showed normal architecture of the white pulp without coalescence or formation of secondary follicles and infiltration of lymphoid cells into red pulp (Supplemental Figure S1A). The IHC analysis of the spleen using antibodies against $\mathrm{T}$ and $\mathrm{B}$ cells and $\mathrm{Ki}-67$ as a proliferation marker depicted a normal segregation of $\mathrm{T}$ lymphocytes in the periarteriolar lymphoid sheaths and B cells in follicles and marginal zones. Both $\mathrm{T}$ and $\mathrm{B}$ cells showed no alterations in nucleus size, chromatin pattern, membrane feature, and shape associated with hematopoietic neoplasms. Lymph nodes of control and Jakl ${ }^{S 645 P+/-}$ mice also showed normal histological features (Supplemental Figure S1B). Consistent with these observations, analysis of the frequencies of leukocyte subsets in peripheral blood 

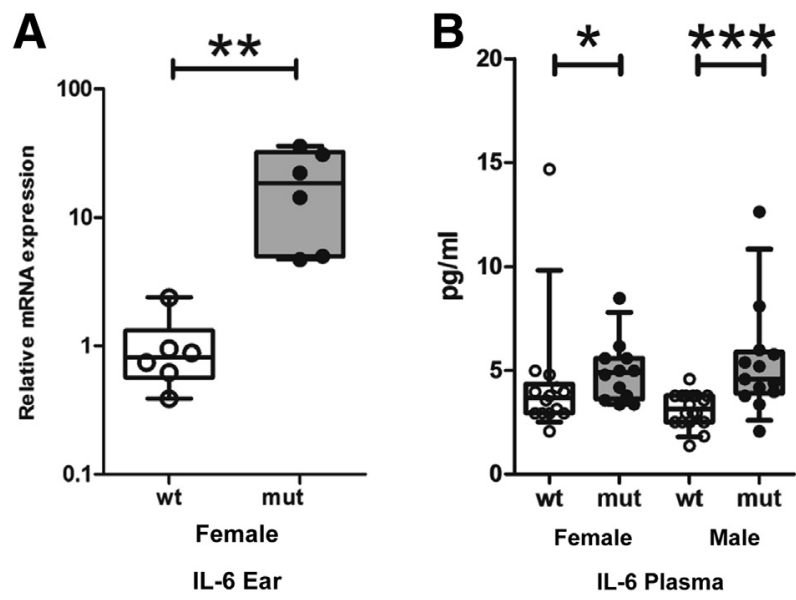

Figure 3 A: IL-6 determination by real-time PCR on ears derived from female Jak1 ${ }^{w t}(n=6)$ and female Jak1 ${ }^{5645 P+/-}(n=6)$ mice showed a significant increase of the expression of IL- 6 mRNA in Jak1 ${ }^{5645 P+/-}$ mice compared with Jak1 ${ }^{w t}(P=0.021)$. B: IL-6 determination in serum of $\mathrm{Jak1}^{\text {wt }}(n=32)$ and Jak1 ${ }^{\text {S645P+/- }}(n=25)$ mice showed a significant increase in IL- 6 levels in female and male Jak1 ${ }^{S 645 P+/-}$ mice compared with Jak1 ${ }^{w t}$. ${ }^{*} P<0.05,{ }^{* *} P<0.01$, and ${ }^{* * *} P<0.001$, as determined by MannWhitney rank-sum test.

by flow cytometry detected no genotype-related differences in the frequencies of $\mathrm{T}$ cells, $\mathrm{B}$ cells, and macrophages, and only sex-dependent changes were monitored (Supplemental Figure S2).

In the red pulp of the spleen, the histological analysis and quantification revealed a significant 50\% loss of megakaryocytes in female and a $75 \%$ loss in male $\mathrm{Jakl}^{\mathrm{S645P+/-}}$ mice, which correlated well with a thrombocytopenia detected in peripheral blood in older animals (Table 3 and Figure 5A). In addition, a slight increase in the number of plasma cells was observed by H\&E staining. By using PAS staining, we visualized Russell bodies, which are large cytoplasmic eosinophilic globules containing immunoglobulin inclusions usually found in a plasma cell undergoing excessive synthesis of immunoglobulin. As shown in Figure 5B, we detected a duplication of the number of Russell bodies in female $\mathrm{Jakl}^{\mathrm{S645P+/-}}$ mice. Male mice have not been examined. These results are further corroborated by significantly increased titers of immunglobulins in serum (Figure 6A). In addition, preliminary real-time PCR experiments with spleen RNA of $\mathrm{Jakl}^{\mathrm{S645P+/}}$ animals showed no significant IL-6 expression (data not shown).

Other organs examined, such as pericardium, pleura, and kidneys, did not show any morphological alterations. Preliminary results of transmission electron microscopy indicate a thickening of mesangium in some glomerula, but require further analysis (data not shown).

\section{Increase in Immunoglobulin Isotype, Autoantibody Levels, and T-Cell Subpopulation}

Analyzing immunological parameters and anti-DNA antibodies in peripheral blood, a general immunoglobulinemia with all immunoglobulin isotype levels being elevated was determined in $\mathrm{Jakl}^{\mathrm{S} 645 \mathrm{P}+/-}$ compared with $\mathrm{Jakl}^{\text {wt }}$ mice. This finding was more pronounced in female mutant mice showing a significant elevation of $\operatorname{Ig} \mathrm{A}, \operatorname{IgG} 1, \operatorname{IgG} 2 \mathrm{a}$, and IgM. A tendency toward elevation without reaching significance was found for IgG3 and IgE (Figure 6A). In male $\mathrm{Jakl}^{\mathrm{S645P+/}}$ mice, a significant difference from Jakl ${ }^{\text {wt }}$ was found for IgG1, IgG2a, and IgM. Again, a tendency toward higher levels was found for $\operatorname{IgA}, \operatorname{IgG} 3$, and $\operatorname{IgE}$. Both male and female $J a k 1^{S 645 P+/-}$ mice developed higher
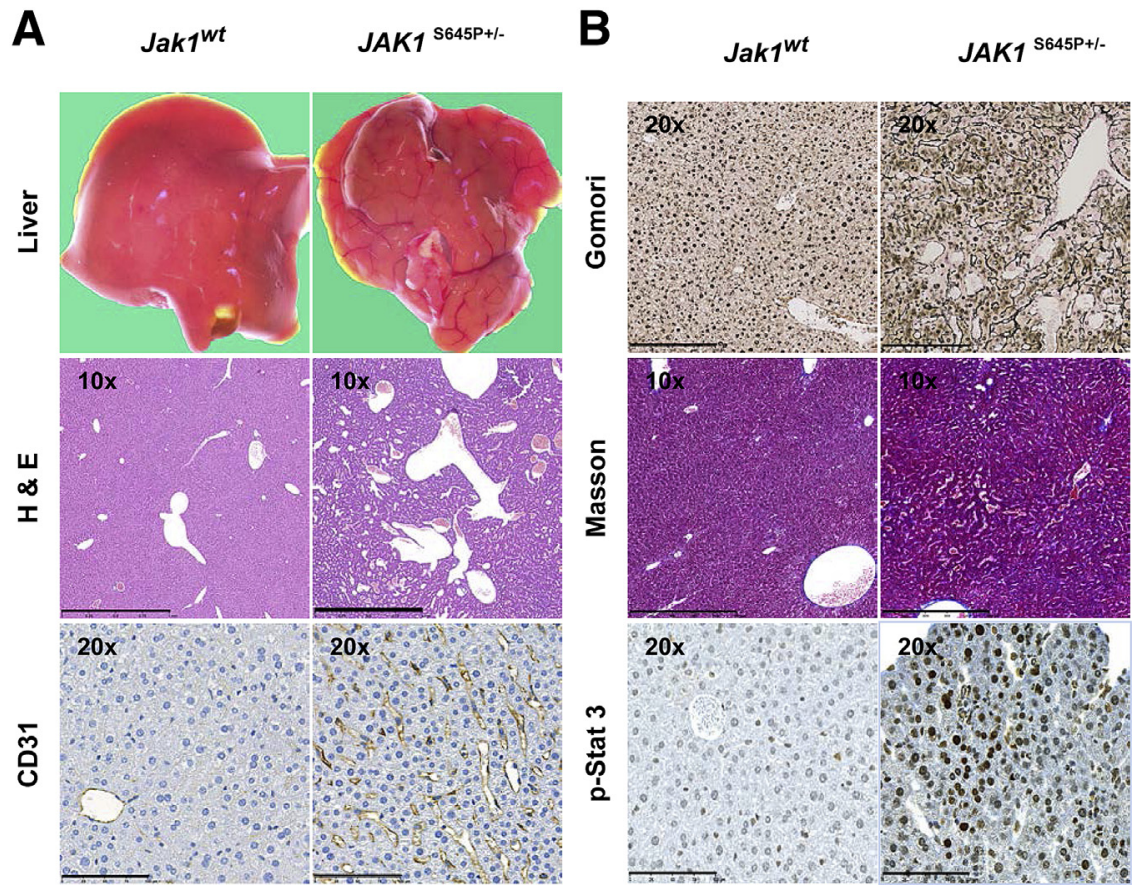

Figure 4 Pathological changes of the liver (NRH). A: Macroscopic appearance of the liver from a Jak $1^{5645 P+/-}$ mouse reveals a congestive liver with irregular margins and prominent vessels. H\&E stainings of the liver show a dilation of the hepatic sinusoidal plexus. Anti-CD31 IHC for endothelial cells illustrates an increased vascularization in the mutant liver. Scale bars: $200 \mu \mathrm{m} ; 500 \mu \mathrm{m}$. B: Reticulin silver staining (Gomori's trichrome staining) visualizes an increase in hyperplastic hepatocytes neighbored by atrophic hepatocytes in a Jak1 $1^{\text {S645P+/- }}$ mouse. Masson's trichrome staining excludes the presence of fibrosis in Jak1 ${ }^{\text {S645P+/- }}$ mice. Anti-p-Stat3 IHC depicts phosphorylation and nuclear localization of Stat3 in the hepatocytes of $\mathrm{Jak1} 1^{\mathrm{S} 645 \mathrm{P}+/-}$ mice compared with Jak1 ${ }^{\text {wt }}$ mice demonstrating activation of the JAK/STAT pathway. Scale bar $=200 \mu \mathrm{m}$. 
New Model for Systemic Autoimmune Disease

Table 2 Female Jak1 ${ }^{S 645 P+/-}$ Mice Show a Significant Increase in Absolute and to Tibia Length Normalized Spleen Weight

\begin{tabular}{|c|c|c|c|c|c|c|c|c|c|c|c|c|c|c|}
\hline \multirow{3}{*}{ Variable } & \multicolumn{12}{|c|}{ Wilcoxon rank-sum test } & \multicolumn{2}{|l|}{$P$ value } \\
\hline & \multicolumn{6}{|l|}{ Female } & \multicolumn{6}{|l|}{ Male } & \multirow{2}{*}{ Female } & \multirow{2}{*}{ Male } \\
\hline & \multicolumn{3}{|c|}{$J a k 1^{w t}(n=10)$} & \multicolumn{3}{|c|}{$\mathrm{Jak1}^{\text {S645P+/- }}(n=10)$} & \multicolumn{3}{|c|}{$J a k 1^{w t}(n=7)$} & \multicolumn{3}{|c|}{$\operatorname{Jak1}^{\text {S645P+/- }}(n=13)$} & & \\
\hline $\begin{array}{l}\text { Spleen weight } \\
\text { (g) }\end{array}$ & 0.11 & 0.101 & 0.123 & 0.127 & 0.116 & 0.145 & 0.103 & 0.095 & 0.148 & 0.094 & 0.087 & 0.1 & 0.034 & 0.151 \\
\hline $\begin{array}{l}\text { Spleen } \\
\text { weight/ } \\
\text { tibia length }\end{array}$ & 0.0063 & 0.0059 & 0.0071 & 0.0075 & 0.0068 & 0.0085 & 0.0061 & 0.0054 & 0.0082 & 0.0055 & 0.0051 & 0.0059 & 0.022 & 0.157 \\
\hline
\end{tabular}

anti-DNA autoantibody titers compared with $J a k l^{\text {wt }}$ mice (Figure 6B).

Although no apparent alteration of frequencies in main leukocyte populations consistent in both sexes were determined, a detailed analysis gating on T-cell subpopulations revealed significantly increased frequencies of Ly-6Cexpressing $\mathrm{CD}^{+} \mathrm{T}$ cells in $\mathrm{Jakl}^{\mathrm{S645P+/-}}$ mice of both sexes (Figure 6C). Furthermore, we set up an in vitro stimulation assay with PMA/ionomycin monitoring cell surface expression of CD71 (the transferrin receptor), which is a cell surface antigen expressed on leukocytes early on activation. ${ }^{39}$ Interestingly, already under non-stimulatory conditions, we discovered a significantly increased expression level of CD71 on T cells, B cells, and nonlymphocytes of Jakl $1^{\text {S645P+/- }}$ mice compared with control mice. PMA/ionomycin stimulation triggered the expression of CD71 in all subpopulations tested (Figure 6D), but only T cells and nonlymphocytes of the $J a k l^{S 645 P+/-}$ mice revealed a higher CD71 level than control mice. In these experiments, we also measured the CD69 expression, ${ }^{40}$ which was at maximum levels after PMA/ionomycin stimulation in cells of mutants and controls. However, preliminary experiments also revealed higher CD69 expression in leukocytes of the $\mathrm{Jak1} 1^{\mathrm{S} 645 \mathrm{P}+/-}$ compared with controls using lower doses of PMA/ ionomycin (data not shown).

\section{Hypophosphatemia, Increased ALP Activities, Elevated} CTX-1, Reduced PTH, and FGF23 Plasma Values

In addition, $J a k 1^{S 645 P+/-}$ mice showed statistically significant changes of several clinical chemical parameters in plasma measured at the ages of 3, 6, 9, and 12 months (Figure 7A and Supplemental Table S1). A strong hypophosphatemia correlated with elevated alkaline phosphatase (ALP) activities, hypocholesterolemia, and hypotriglyceridemia, in both female and male $J a k 1^{S 645 P+/-}$ mice. Hypoglucosemia was observed from the age of 6 months onward in mutant mice of both sexes at all time points. Only male mice depicted hypercalcemia at the age of 12 and 24 weeks. In addition, parameters related to protein metabolism and kidney function were altered in various degrees in mice at different age points. Urea was decreased in female and male $\mathrm{Jakl} 1^{\mathrm{S} 645 \mathrm{P}+1-}$ mice at the age of 3 months; this phenotype obviously improved with age. Uric acid was elevated with 3 months in both female and male Jakl $1^{S 645 P+/-}$ mice and female Jakl ${ }^{\text {S645P+/- }}$ mice at the age of 6 months. The values were decreased in 9- and

Table 3 Hematological Data Obtained in 4.5-Month-0ld Jak1 $1^{5645 P 4+/-}$ Mice and Jak1 $1^{w t}$ Littermate Controls

\begin{tabular}{|c|c|c|c|c|c|c|c|}
\hline \multirow[b]{2}{*}{ Parameter } & \multicolumn{2}{|l|}{ Female } & \multicolumn{2}{|l|}{ Male } & \multicolumn{3}{|c|}{ Linear model $P$ value } \\
\hline & $J a k 1^{w t}(n=8)$ & $J a k 1^{S 645 P+/-}(n=6)$ & $\operatorname{Jak1}^{w t}(n=9)$ & $\operatorname{Jak1}^{\mathrm{S} 645 P+/-}(n=11)$ & Genotype & Sex & Genotype:sex ratio \\
\hline $\mathrm{RBC}\left(\mathrm{Mio} / \mathrm{mm}^{3}\right)$ & $9.11 \pm 0.27$ & $9.39 \pm 0.32$ & $8.88 \pm 0.48$ & $9.43 \pm 0.36$ & 0.006 & 0.530 & 0.335 \\
\hline HCT (\%) & $43.3 \pm 1.17$ & $41.0 \pm 1.40$ & $43.3 \pm 2.66$ & $42.2 \pm 1.70$ & 0.019 & 0.367 & 0.421 \\
\hline $\mathrm{MCV}(\mathrm{fL})$ & $47.5 \pm 0.49$ & $43.7 \pm 0.64$ & $48.8 \pm 0.79$ & $44.8 \pm 1.76$ & $<0.001$ & 0.009 & 0.810 \\
\hline $\mathrm{MCH}(\mathrm{pg})$ & $14.98 \pm 0.24$ & $13.82 \pm 0.20$ & $15.17 \pm 0.33$ & $14.02 \pm 0.54$ & $<0.001$ & 0.175 & 0.972 \\
\hline WBC $\left(10^{3} / \mathrm{mm}^{3}\right)$ & $4.97 \pm 0.6$ & $6.45 \pm 1.7$ & $5.26 \pm 1.0$ & $4.66 \pm 1.5$ & 0.355 & 0.122 & 0.034 \\
\hline $\operatorname{PLT}\left(10^{3} / \mathrm{mm}^{3}\right)$ & $1401 \pm 229$ & $1442 \pm 192$ & $1328 \pm 218$ & $1261 \pm 146$ & 0.856 & 0.093 & 0.467 \\
\hline MPV (fL) & $7.29 \pm 0.20$ & $6.87 \pm 0.20$ & $7.46 \pm 0.25$ & $6.72 \pm 0.21$ & $<0.001$ & 0.904 & 0.059 \\
\hline PDW (fL) & $8.39 \pm 0.42$ & $7.85 \pm 0.63$ & $8.72 \pm 0.57$ & $7.51 \pm 0.55$ & $<0.001$ & 0.988 & 0.108 \\
\hline P-LCR $(\%)$ & $9.90 \pm 1.10$ & $7.47 \pm 1.43$ & $11.10 \pm 1.47$ & $6.81 \pm 1.30$ & $<0.001$ & 0.589 & 0.071 \\
\hline
\end{tabular}

$\mathrm{HCT}$, hematocrit; $\mathrm{HGB}$, hemoglobin; $\mathrm{MCH}$, mean cellular hemoglobin content; MCHC, mean corpuscular hemoglobin concentration; MCV, mean corpuscular volume; Mio, million; MPV, mean platelet volume; PDW, red blood cell distribution width; P-LCR, platelet large cell ratio; PLT, platelet count; RBC, red blood cell; RDW, red blood cell distribution width; WBC, white blood cell count. 
12-month-old male $J a k 1^{S 645 P+/-}$ mice. Total protein, creatinine, and albumin in plasma showed sex- and age-related alterations in $\mathrm{Jakl}^{\mathrm{S645P+/-}}$ mice.

Hematological analysis detected significantly increased red blood cell counts accompanied by more pronounced anisocytosis in first measurements of 4.5-month-old (data not

A Megakaryocytes
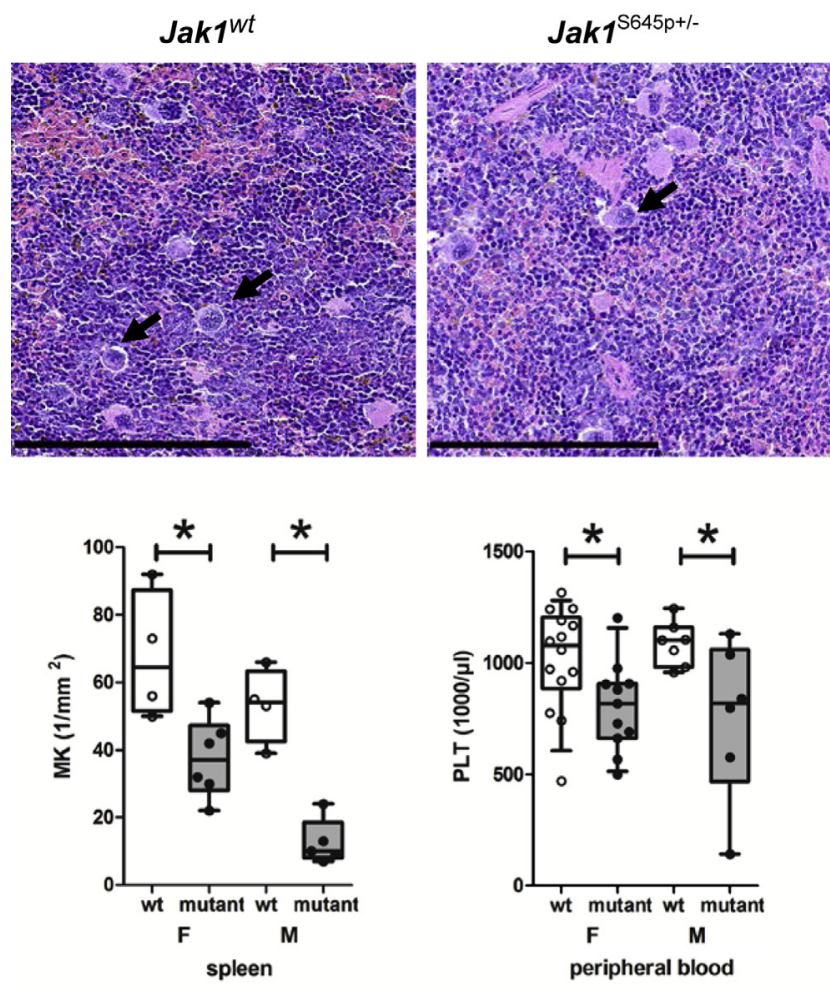

B

Russell bodies
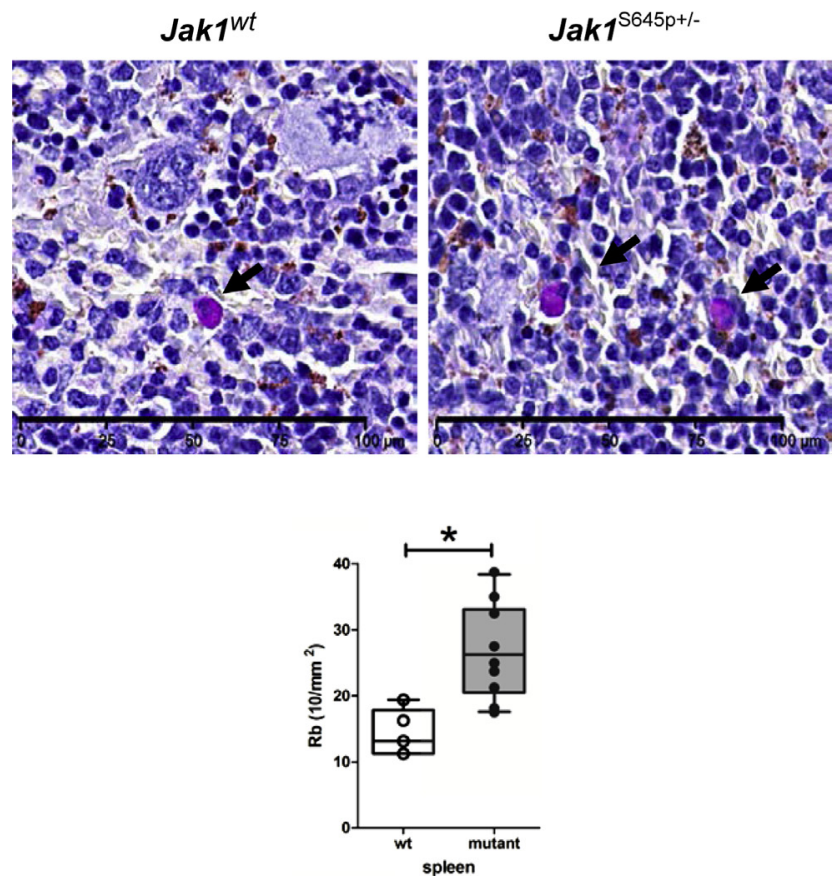

shown) and 6-month-old $J a k 1^{S 645 P+/-}$ mice, indicated by elevated red cell distribution width in mutant animals compared with the corresponding controls. At the same time, the mean corpuscular volume and cellular hemoglobin content were decreased in these animals. The mean platelet volume was decreased in mutant mice because of a reduction of the large cell fraction, shown by a reduced platelet:large cell ratio (Table 3). Thrombocytopenia was confirmed in 7- to 14month-old female and male $\mathrm{Jakl}^{\mathrm{S645P+/-}}$ mice (Figure 5A), which was associated with increased platelet distribution width. Taken together, the results obtained in $\mathrm{Jakl}^{\mathrm{S} 645 \mathrm{P}+/-}$ mice indicate a microcytic, erythropenic anemia with increased anisocytosis and reticulocyte proportion.

To elucidate the hypophosphatemia and the elevated ALP activities, we measured plasma levels of PTH in 12week-old mice and of FGF23 in 20-week-old mice. PTH and FGF23 plasma concentrations were significantly lower in $\mathrm{Jakl}^{\mathrm{S645P+/-}}$ mice. PTH measurements in female mutant mice $(n=9)$ revealed mean values of $45.605 \pm$ $27.83 \mathrm{pg} / \mathrm{mL}$ compared with $122.551 \pm 41.726 \mathrm{pg} / \mathrm{mL}$ in Jakl ${ }^{w t}$ mice $(n=5)(P \leq 0.001)$. Male Jakl $1^{S 645 P+/-}$ mice $(n=6)$ showed a mean of $37.097 \pm 9.369 \mathrm{pg} / \mathrm{mL}$ compared with $87.709 \pm 21.709 \mathrm{pg} / \mathrm{mL}$ measured in Jakl ${ }^{w t}$ mice $(n=9)(P \leq 0.001)$. FGF23 values were a mean of $68.250 \pm 33.605 \mathrm{pg} / \mathrm{mL}$ for female $J a k l^{S 645 P+/-}$ mice $(n=$ 12) compared with $166.556 \pm 46.101 \mathrm{pg} / \mathrm{mL}$ in $J a k l^{w t}$ mice $(n=9)$. Male $J a k 1^{S 645 P+/-}$ mice showed a median of

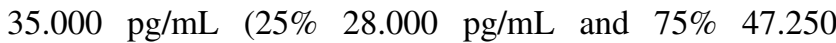
$\mathrm{pg} / \mathrm{mL})$, compared with $J a k 1^{w t}$ mice showing a median of $155.000 \mathrm{pg} / \mathrm{mL}(25 \% 118.500 \mathrm{pg} / \mathrm{mL}$ and $75 \% 196.000$ $\mathrm{pg} / \mathrm{mL})(P \leq 0.001$ calculated by the Mann-Whitney ranksum test because of value distributions). Because PTH and FGF23 are involved in phosphate homeostasis and bone mineral metabolism, we further analyzed an additional plasma parameter for the assessment of bone metabolism using a CTX-1 ELISA. Indeed, Jakl $1^{\text {S645P+/- }}$ mice showed

Figure 5 Pathological changes of the spleen. A: Top panel: Representative $H \& E$ staining of the spleen shows a reduction in the number of megakaryocytes (arrows) in Jak $1^{5645 P+/-}$ compared with Jak1 $1^{\text {wt }}$ mice. Scale bar $=$ $200 \mu \mathrm{m}$. Bottom left panel: Quantification of megakaryocytes (MKs) determined from hematoxylin staining of Jak $1^{w t}$ spleen $(n=8)$ and mutant spleen $(n=11)$. For statistics, three identical areas within the red pulpa were evaluated for MK numbers. A significant decrease of MK was obtained $[P=$ 0.01905 for females (F) and $P=0.00024$ for males (M)], as determined by the Wilcoxon rank-sum test. Bottom right panel: Thrombocytopenia was demonstrated by a significant decrease of platelets counts (PTLs; in $10^{3}$ cells $/ \mu \mathrm{L}$ ) in peripheral blood from Jak $1^{5645 P+/-}$ mice compared with Jak $1^{\text {wt }}$ mice determined at the age of 11 months $(P=0.0206$ for females and $P=0.0719$ for males, as determined by the Wilcoxon rank-sum test). B: The number of Russell bodies demonstrated by PAS staining of the spleen was increased in Jak1 $1^{5645 P+/-}$ mice compared with Jak1 ${ }^{\text {wt }}$ control animals (Rb; arrows). Original magnification, $\times 40$. Scale bar $=100 \mu \mathrm{m}$. Bottom panel: Quantification of Russell bodies (Rbs) determined from PAS staining of female Jak ${ }^{\text {wt }}$ spleen $(n=5)$ and female Jak $1^{S 645 P+/-}$ mutant spleen $(n=10)$. For statistics, two identical areas within the red pulpa were evaluated. A duplication of the number of Rbs in Jak $1^{5645 P+/-}$ mice was obtained $(P=0.003)$, as determined by the Wilcoxon rank-sum test. Asterisks denote statistically significant comparisons. 

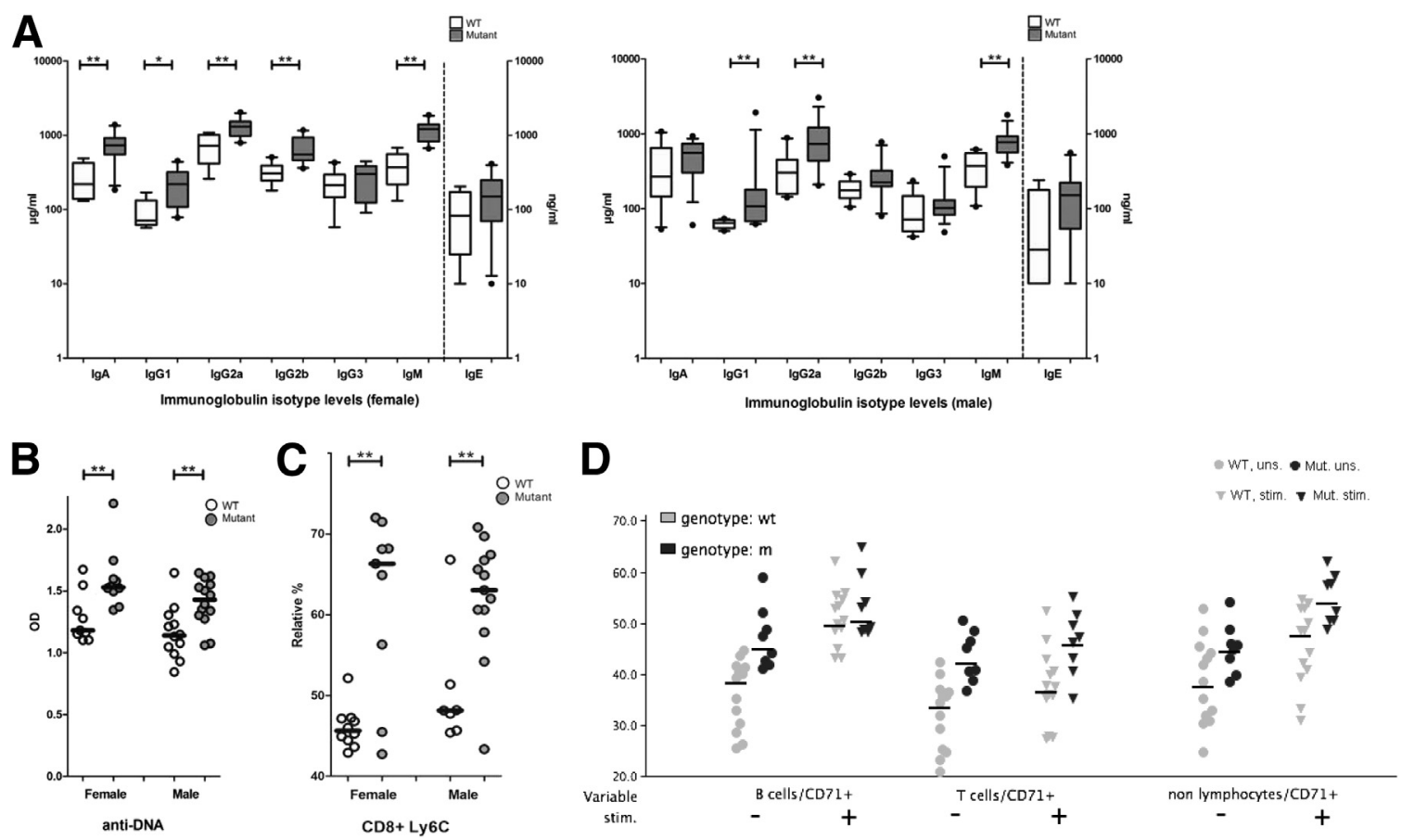

Figure 6 A: Determination of immunoglobulins in plasma samples reveals elevated levels of all immunoglobulin isotypes in Jak1 ${ }^{S 645 P+/-}$ mice $(n=20)$ compared with Jak1 $1^{w t}$ mice $(n=20)$. These differences were more clear-cut in females than in males. Immunoglobulin concentrations are given in $\mu \mathrm{g} / \mathrm{mL}$, except for IgE $(\mathrm{ng} / \mathrm{mL})$. B: Specific immunoglobulin levels against DNA. Specific immunoglobulin titers against DNA show significantly higher values in the Jak1 ${ }^{\text {S645P+/- }}$ mice compared with the Jak1 ${ }^{\text {wt }}$ mice. C: Determination of Ly- $6 \mathrm{C}$-expressing cells within the CD8 ${ }^{+} \mathrm{T}_{\text {-cell }}$ cluster in blood samples from Jak1 ${ }^{\text {S645P+/- }}$ mice $(n=20)$ and Jak $1^{w t}$ mice $(n=20)$, given as percentage of CD8 ${ }^{+}$T cells, demonstrates significantly increased frequencies of Ly-6C CD8 ${ }^{+} \mathrm{T}$ cells in Jak1 ${ }^{5645 P+/-}$ mice of both sexes compared with Jak1 ${ }^{\text {wt }}$ mice. D: Determination of frequencies of CD71-expressing cells within the corresponding cell clusters (B cells, T cells, and nonlymphocytes) in non-stimulated (uns.) and PMA/ionomycin-stimulated (stim.) blood samples from Jak $1^{5645 P+/-}$ mice $(n=$ $8)$ and Jak1 $1^{\text {wt }}$ mice $(n=13)$ given as percentage of the corresponding parent gate. Frequencies of CD71-expressing cells within the B-cell, T-cell, and nonlymphocyte clusters are significantly increased in non-stimulated samples from Jak1 $1^{S 645+/-}$ compared with Jak1 $1^{\text {wt }}$ mice. After 4 hours of stimulation with PMA/ionomycin, we found increased frequencies of CD71-expressing cells with the T-cell and nonlymphocyte clusters compared with Jak1 ${ }^{\text {wt }}$ mice. Mutant (Mut.), Jak1 ${ }^{5645 P+/-}$; WT, Jak1 ${ }^{w t} .{ }^{*} P<0.05,{ }^{*} P<<0.01$, as determined by the Mann-Whitney rank-sum test.

significantly increased values of collagen type I fragments generated during osteoclastic bone resorption compared with $J a k I^{w t}$ mice when measured in 3-, 6-, 9-, and 12month-old mice. CTX-1, PTH, and FGF23 levels are shown in Figure 7A and Supplemental Table S1.

To study whether the decreased $\mathrm{P}_{\mathrm{i}}$ plasma levels in $J a k 1^{S 645 P+/-}$ mice were the result of an increased $\mathrm{P}_{\mathrm{i}}$ excretion through the kidney, we performed urine analysis in both mutant and WT mice at the age of 18 to 21 weeks. The measurement of seven mutant and eight WT female and of eleven mutant and nine WT male mice in metabolic cages provided no changes in $\mathrm{P}_{\mathrm{i}}$, calcium, and creatinine excretion between the two genotypes.

\section{Osteopenic Bone Phenotype of Jak1 ${ }^{S 645 P+/-}$ Mice}

The strong hypophosphatemia, high ALP activities, and the elevated CTX-1 levels are expected to be due to an impaired bone metabolism in $\mathrm{Jakl}^{\mathrm{S645P+/-}}$ mice. Thus, parameters related to disturbed bone mineralization were measured using suitable imagine systems, such as pQCT and $\mu \mathrm{CT}$ analysis, in 22- to 23-week- and 12-month-old mice. In pQCT measurements, female and male $\mathrm{Jakl}^{\mathrm{S} 645 \mathrm{P}+/-}$ mice showed strong decreased values of almost all parameters analyzed at the age of both 22 to 23 weeks (Tables 4 and 5) and 12 months (Tables 6 and 7) in femoral metaphysis and diaphysis. The trabecular area was increased in all measurements for both female and male $J a k l^{S 645 P+/-}$ mice.

First, $\mu \mathrm{CT}$ measurement of three female $\mathrm{Jakl}^{\mathrm{S} 645 \mathrm{P}+/-}$ and Jakl ${ }^{w t}$ mice, aged 12 months, showed that mutant mice lost almost all metaphyseal and diaphyseal trabeculae compared with $J a k I^{w t}$ mice (Figure 7B). This measurement confirmed the observations made by pQCT measurement showing decreased values of trabecular density, trabecular content, bone volume:tissue ratio, trabecular bone surface, and trabecular number for trabecular bone. In cortical bone periosteal volume, cortical bone volume and cross-sectional thickness were significantly decreased, and endosteal volume was increased in $\mathrm{Jakl}^{\mathrm{S} 645 \mathrm{P}+/-}$ mice.

\section{Genotyping}

Linkage analysis using a genome-wide murine panel of 158 single-nucleotide polymorphism markers ${ }^{30}$ revealed a large candidate region on distal chromosome 4 between the single-nucleotide polymorphism markers $r s 28056583$ and rs13469808 (86.81 to $117.55 \mathrm{Mb}$, mouse genome Build 37.1; University of California, Santa Cruz). After FACS-based 
A

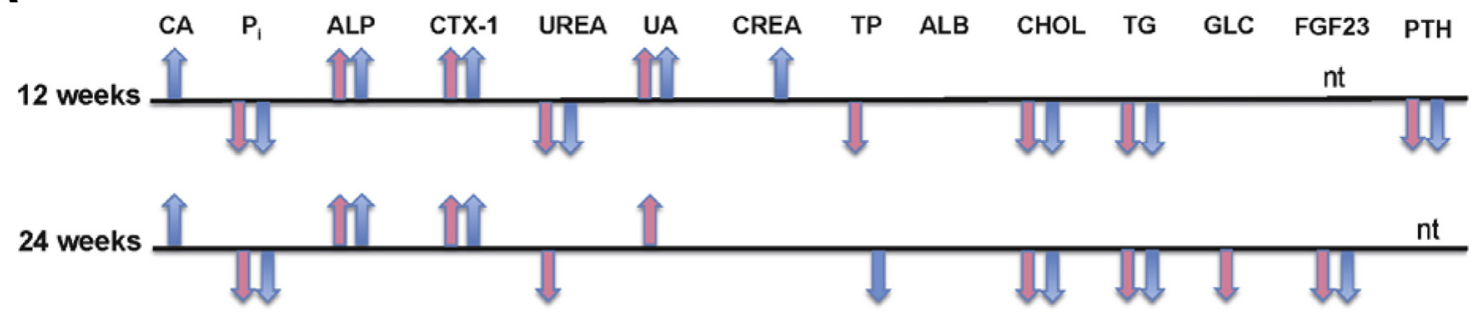

36 weeks
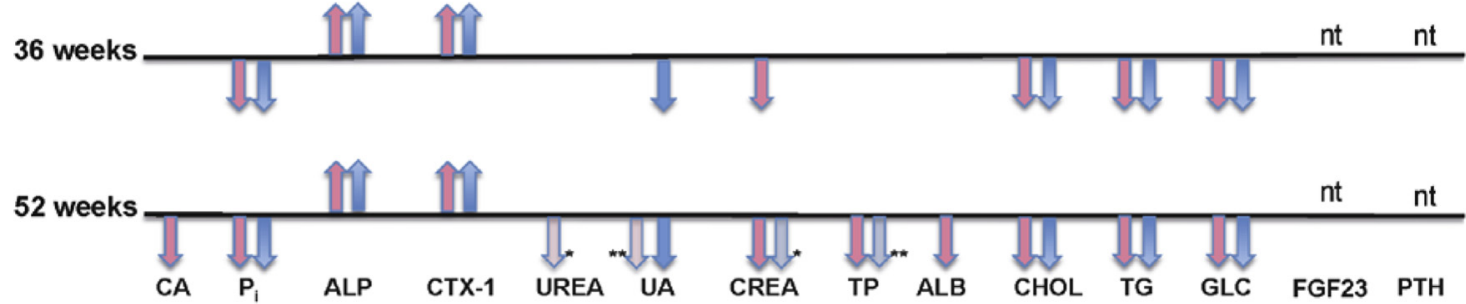

B
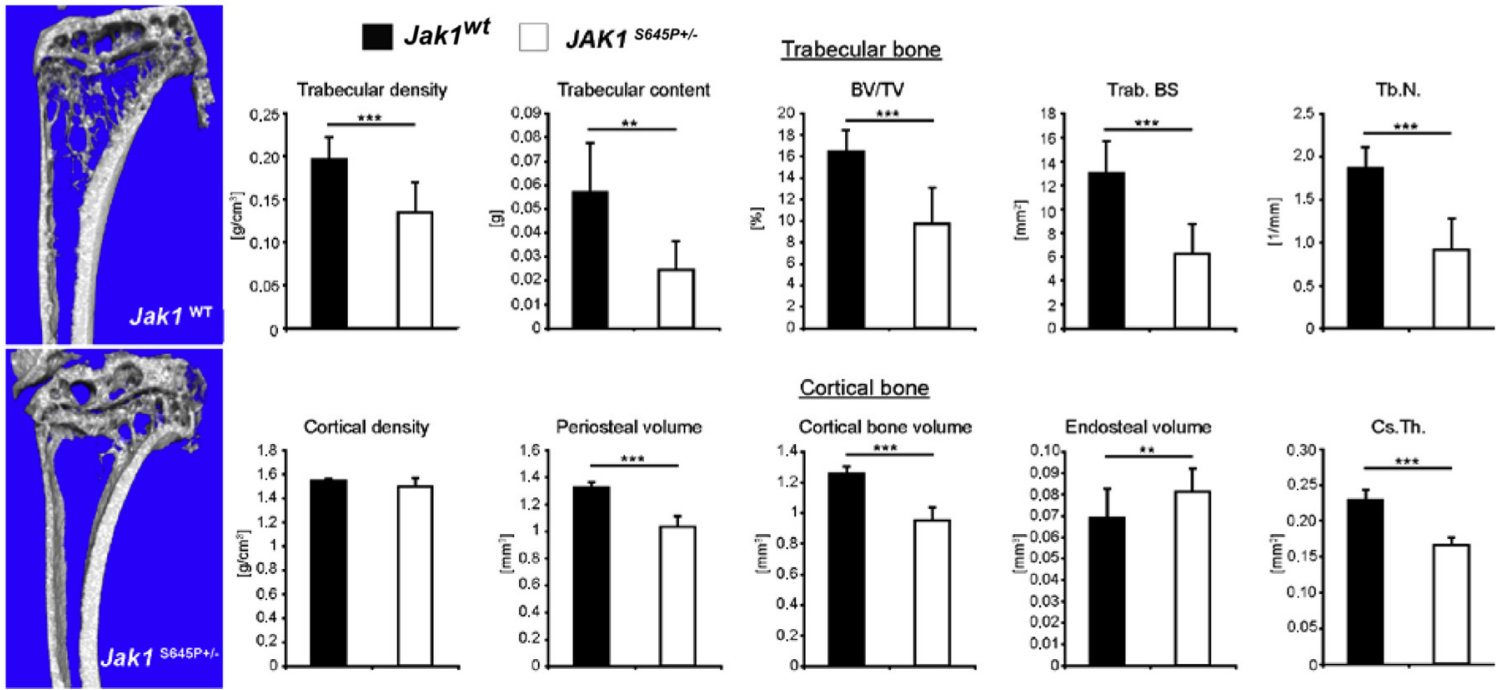

Figure 7 A: Overview on statistically significant plasma value changes obtained in Jak $1^{5645 \mathrm{P}+/-}$ mice compared with their WT littermate controls at the age of $12,24,36$, and 52 weeks. Blue and red arrows denote male and female Jak1 ${ }^{5645 P+/-}$ mice showing significantly increased or decreased alterations for each parameter. Blank fields indicate no changes. Red arrow with one asterisk denotes tendency to decreased values $(P=0.191)$. Red arrow with two asterisks denotes tendency to decreased values $(P=0.372)$. Blue arrow with one asterisk denotes tendency to decreased values $(P=0.057)$. Blue arrow with two asterisks denotes tendency to decreased values $(P=0.057)$. Accordingly, blood values \pm SEM $(S D)$ and $P$ values are found in Supplemental Table S1. B: Bone phenotype of Jak1 $1^{5645 P+/-}: \mu \mathrm{CT}$ analysis of 12 -month-old Jak1 $1^{S 645 P}$ tibia. Representative three-dimensional reconstruction of Jak1 ${ }^{\text {wt }}$ control (top panel) and Jak $1^{5645 P+/-}$ tibia (bottom panel). Histomorphometric analysis of the trabecular portion (top panel) revealed decreased values in Jak $1^{5645 P+/-}$ mice. In addition, cortical parameters (bottom panel) exhibit significantly declined values in mutant tibial bones. Endosteal bone volume was calculated as follows: Periosteal Volume - Cortical Bone Volume. ALB, albumin; BV/TV, bone volume/tissue volume; CA, inorganic total calcium; CHOL, total cholesterol; CREA, creatinine; Cs.Th., cross-sectional thickness; GLS, glucose; nt, not tested; Tb.N., trabecular number; TG, triglyceride; TP, total protein; Trab.BS, trabecular bone surface UA, uric acid. ${ }^{* *} P<0.01,{ }^{* *} P<0.001$ (analysis of variance).

chromosome sorting, we sequenced 6.09 and $6.3 \mathrm{~Gb}$ of the sorted mouse mutant and WT whole chromosomes, respectively. A comparison of nonsynonymous single-nucleotide variants (SNVs) between the mutant and the control strain revealed six homozygous and two heterozygous SNVs within the candidate region. Validation of the SNVs by capillary sequencing of genomic DNA from phenotypic mutant and WT mice confirmed the identified SNVs within the Jakl, Skint5, Cyp4a30b, Eif2b3, and Grhl3 genes. Only the Jakl sequence variation (uc008tvk.1 c.1933T >C, p.Ser645Pro) cosegregated with the phenotype in 18 phenotypic mutant mice and was not found in $>20$ control mice.

\section{Discussion}

The JAK-STAT pathway has proved to be essential for many immunological processes playing a critical role in the pathogenesis of autoimmune diseases and cancer. ${ }^{14,41}$ 
New Model for Systemic Autoimmune Disease

Table 4 Bone-Related Quantitative Parameters (22- to 23-Week-Old Mice) Obtained by pQCT Measurement of Femoral Metaphysis

\begin{tabular}{|c|c|c|c|c|c|c|c|}
\hline \multirow[b]{2}{*}{ Parameter } & \multicolumn{2}{|l|}{ Jak1 ${ }^{S 645 P+/+}$} & \multicolumn{2}{|l|}{ Jak1 $1^{\text {S645P+/- }}$} & \multicolumn{2}{|c|}{ WT:mut $P$ value } & \multirow{2}{*}{$\begin{array}{l}\text { ANOVA } P \text { value } \\
\text { (genotype:sex } \\
\text { ratio) }\end{array}$} \\
\hline & Female & Male & Female & Male & Female & Male & \\
\hline Total density $\left(\mathrm{mg} / \mathrm{cm}^{3}\right)$ & $782 \pm 11$ & $646 \pm 10$ & $689 \pm 5$ & $531 \pm 7$ & $<0.0001$ & $<0.0001$ & $<0.0001$ \\
\hline Trabecular density $\left(\mathrm{mg} / \mathrm{cm}^{3}\right)$ & $302 \pm 5$ & $316 \pm 7$ & $275 \pm 6$ & $250 \pm 7$ & $<0.01$ & $<0.0001$ & $<0.0001$ \\
\hline Cortical density $\left(\mathrm{mg} / \mathrm{cm}^{3}\right)$ & $905 \pm 8$ & $826 \pm 6$ & $868 \pm 8$ & $785 \pm 5$ & $<0.01$ & $<0.0001$ & $<0.0001$ \\
\hline Total content (mg) & $2.58 \pm 0.04$ & $2.28 \pm 0.04$ & $2.05 \pm 0.05$ & $1.60 \pm 0.05$ & $<0.0001$ & $<0.0001$ & $<0.0001$ \\
\hline Total area $\left(\mathrm{mm}^{2}\right)$ & $3.31 \pm 0.07$ & $3.53 \pm 0.05$ & $2.97 \pm 0.07$ & $3.01 \pm 0.07$ & $<0.01$ & $<0.0001$ & $<0.0001$ \\
\hline Trabecular area $\left(\mathrm{mm}^{2}\right)$ & $0.68 \pm 0.05$ & $1.23 \pm 0.07$ & $0.90 \pm 0.03$ & $1.44 \pm 0.04$ & $<0.01$ & $<0.05$ & $<0.001$ \\
\hline Cortical area $\left(\mathrm{mm}^{2}\right)$ & $2.63 \pm 0.05$ & $2.30 \pm 0.07$ & $2.08 \pm 0.05$ & $1.58 \pm 0.04$ & $<0.0001$ & $<0.0001$ & $<0.0001$ \\
\hline
\end{tabular}

$n=10$ per group. Data are presented as means \pm SEM.

ANOVA, analysis of variance; mut, mutant.

Activating mutations of the JAK family members have been described numerously in patients with various hematological malignancies, including JAK1 mutations identified in $18 \%$ of patients with adult precursor T-acute lymphoblastic leukemias and in a few acute myeloid leukemias. ${ }^{17,42}$ In particular, point mutations in the pseudokinase domain are reported to be critical for the pathological basis of disease. ${ }^{43-45}$ However, the lack of successful mouse models for mutation-activated JAK-induced diseases hampers the understanding of disease pathological features.

Herein, we present an ENU mutagenesis-derived Jak1 ${ }^{\text {S645P }}$ mouse model with an activating Jakl mutation characterized by strong morphological alterations of the skin, liver, spleen, and bone, accompanied by significant $\mathrm{P}_{\mathrm{i}}$, ALP, CTX-1, PTH, FGF23, and hematological plasma changes. By nextgeneration sequencing techniques, we identified in mutant mice a nonsynonymous sequence variation (c.1933T $>$ C, p.Ser645Pro) within the pseudokinase domain of the Jakl gene not found in $J a k l^{w t}$ littermates. This mutation corresponds to a somatic human mutation in the JAKl gene (p.Ser646Phe) reported in a patient with high-risk pediatric acute lymphoblastic leukemia and was shown to trigger a constitutive activation of the JAK/STAT pathway demonstrated, for example, by increased phosphorylation of
STATs ${ }^{46}$ The phenotypes observed in $\mathrm{Jakl}^{\mathrm{S645P+/-}}$ mice have not been found in knockout $\mathrm{Jakl}^{-1-}$ mice dying prenatally, ${ }^{47}$ making heterozygous mice of this mouse line a worthy model to study Jakl function.

The spontaneous lesions of the skin developed in Jakl ${ }^{\text {S645P+/- }}$ mice had several histological changes described in chronic inflammation, such as angiogenesis, collagen deposition, and granulation tissue formation. Interestingly, similar skin lesions have been described in MRL/lpr mice, which develop a systemic lupus erythematosus (SLE)-like phenotype, including lymphadenopathy, splenomegaly, elevated serum antinuclear autoantibodies, including anti-double-stranded DNA, IgG (majority IgG2a and IgG3), and immune complexmediated glomerulonephritis. ${ }^{3,48,49}$ Consistent with the skin phenotype, the $\mathrm{Jakl}^{\mathrm{S} 645 \mathrm{P}+/-}$ mice showed a global increase of immunoglobulin isotype levels and autoDNA antibodies in circulation. These features are typical findings in patients with $\mathrm{SLE},{ }^{50}$ with a more pronounced increase in females, ${ }^{51}$ because we also observed them in female $J a k 1^{S 645 P+/-}$ mice mimicking the human situation.

The molecular analysis of the JAK-STAT pathway in skin lesions developed by $\mathrm{Jakl}^{\mathrm{S645P+/-}}$ mice revealed an activation of Stat3. In SLE, activated Stat3 is reported to cause an autocrine up-regulation of the IL-6-IL-6

Table 5 Bone-Related Quantitative Parameters (22- to 23-Week-Old Mice) Obtained by pQCT Measurement of Femoral Diaphysis

\begin{tabular}{|c|c|c|c|c|c|c|c|}
\hline \multirow[b]{2}{*}{ Parameter } & \multicolumn{2}{|l|}{ Jak1 ${ }^{w t}$} & \multicolumn{2}{|l|}{$J a k 1^{S 645 P+/-}$} & \multicolumn{2}{|c|}{ WT:mut $P$ value } & \multirow{2}{*}{$\begin{array}{l}\text { ANOVA } P \text { value } \\
\text { (genotype:sex } \\
\text { ratio) }\end{array}$} \\
\hline & Female & Male & Female & Male & Female & Male & \\
\hline Total density $\left(\mathrm{mg} / \mathrm{cm}^{3}\right)$ & $1050 \pm 11$ & $1000 \pm 12$ & $927 \pm 15$ & $872 \pm 8$ & $<0.0001$ & $<0.0001$ & $<0.0001$ \\
\hline Trabecular density $\left(\mathrm{mg} / \mathrm{cm}^{3}\right)$ & $202 \pm 9$ & $208 \pm 7$ & $178 \pm 3$ & $183 \pm 4$ & $<0.05$ & $<0.01$ & $<0.001$ \\
\hline Cortical density $\left(\mathrm{mg} / \mathrm{cm}^{3}\right)$ & $1170 \pm 4$ & $1144 \pm 7$ & $1107 \pm 11$ & $1061 \pm 6$ & $<0.0001$ & $<0.0001$ & $<0.0001$ \\
\hline Total content (mg) & $2.04 \pm 0.05$ & $2.12 \pm 0.04$ & $1.61 \pm 0.06$ & $1.54 \pm 0.06$ & $<0.001$ & $<0.0001$ & $<0.0001$ \\
\hline Total area $\left(\mathrm{mm}^{2}\right)$ & $1.94 \pm 0.06$ & $2.13 \pm 0.04$ & $1.74 \pm 0.05$ & $1.77 \pm 0.06$ & $<0.05$ & $<0.001$ & $<0.0001$ \\
\hline Trabecular area $\left(\mathrm{mm}^{2}\right)$ & $0.25 \pm 0.02$ & $0.33 \pm 0.02$ & $0.34 \pm 0.01$ & $0.38 \pm 0.02$ & $<0.01$ & $<0.05$ & $<0.001$ \\
\hline Cortical area $\left(\mathrm{mm}^{2}\right)$ & $1.70 \pm 0.04$ & $1.80 \pm 0.03$ & $1.40 \pm 0.05$ & $1.40 \pm 0.05$ & $<0.001$ & $<0.0001$ & $<0.0001$ \\
\hline
\end{tabular}

$n=10$ per group. Data are presented as means \pm SEM.

ANOVA, analysis of variance; mut, mutant. 
Table 6 Bone-Related Quantitative Parameters (12-Month-Old Mice) Obtained by pQCT Measurement of Femoral Metaphysis

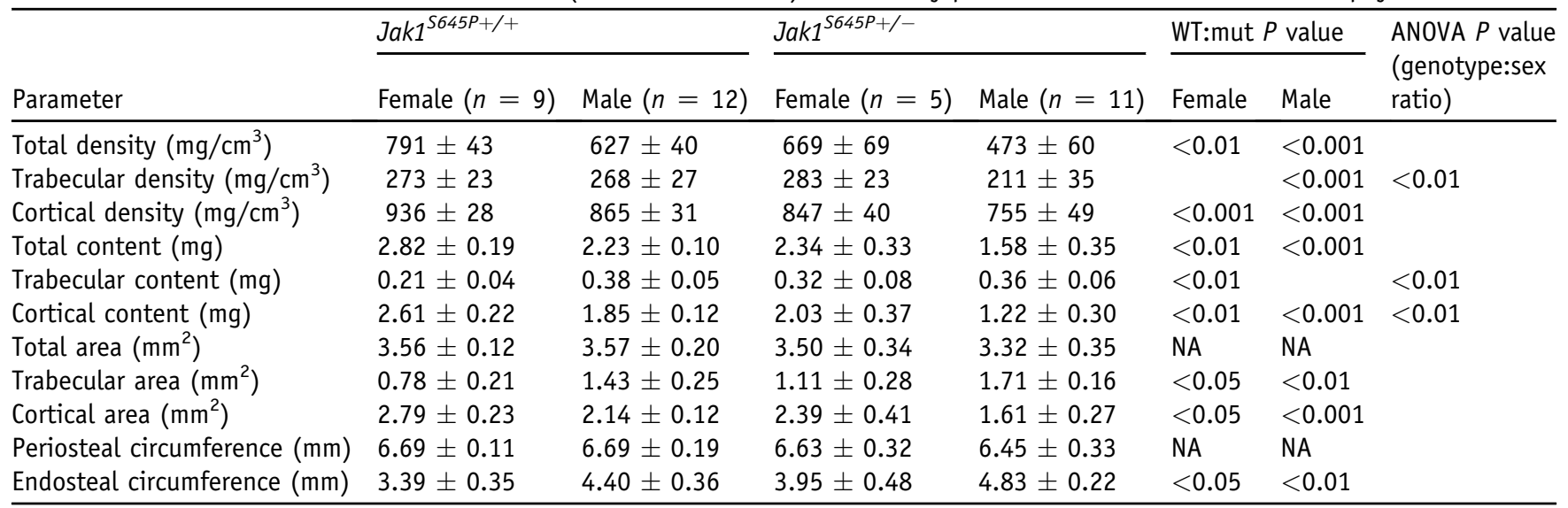

Data are presented as means \pm SEM.

ANOVA, analysis of variance; mut, mutant; NA, not analyzed.

receptor-Stat3 axis, ${ }^{33}$ which triggers increased IL-6 production traced to the epidermis. ${ }^{34}$ The phosphorylation of gp130 occurs downstream of IL- $6,{ }^{26,36,37}$ which we also observed in in $\mathrm{Jakl}^{\mathrm{S645P+/-}}$ mice. Studies in murine models indicate an essential role for IL-6 in SLE, ${ }^{52}$ and development of an SLE phenotype was linked to up-regulated IL-6 signaling, as shown in JunB ${ }^{\Delta E P}$ mice. ${ }^{34}$ Increased levels of IL-6 have also been observed in serum of patients with SLE, especially during disease activity. ${ }^{53,54}$ We observed that Jakl $1^{\text {S645P+/- }}$ mice showed a strong increase of IL-6 and elevated phosphorylation of IL-6 receptor gp130 and Stat-3 in the dermis. These new findings emphasize that Jakl $1^{\text {S645P+/- }}$ mice might model human SLE.

Patients with SLE can also have increased serum IFN $\alpha$ levels, ${ }^{55,56}$ and deficiency of $I F N A R^{-/-}$protects mice from lupus. ${ }^{57}$ An investigation of skin lesions revealed an increased phosphorylation of the IFN $\alpha$ receptor, IFNAR, in Jakl ${ }^{S 645 P+/-}$ mice. Consistent with our data, recently, Ramirez-Velez et $\mathrm{al}^{58}$ demonstrated a constitutive phosphorylation of IFN $\alpha$-associated signaling proteins, in particular phosphorylation of JAK1, in serum of patients with SLE.

Jakl $1^{\text {S645P+/- }}$ mice developed NRH of the liver and showed elevated ALP activities in plasma. NRH was described in autoimmune disease, in a high incidence in SLE cases, ${ }^{59-63}$ and correlated with increased ALP activities and thrombocytopenia in SLE. JAK-STAT signaling pathways have been shown to play a crucial role in the development of NRH in transgenic mice expressing IL-6 and IL-6 receptor. ${ }^{64}$ Coherently, we observed increased phosphorylation of Stat 3 in the liver downstream of the IL6-JAK-STAT axis.

In mice, the spleen is a primary hematopoietic organ equivalent to human bone marrow. ${ }^{65,66}$ The architecture of the spleen was not alternated in $\mathrm{Jakl}^{\mathrm{S} 645 \mathrm{P}+/-}$ mice, concluding that the $J a k 1^{S 645 P+/-}$ mutation is not associated with hematopoietic neoplasms, in contrast to what has been reported for the human $J A K 1$ mutation $(\mathrm{S} 646 \mathrm{~F}){ }^{42,46}$ In Jakl ${ }^{\text {S645P+/- }}$ mice, a slight increase in plasma cell number was observed associated with a duplication of Russell

Table 7 Bone-Related Quantitative Parameters (12-Month-Old Mice) Obtained by pQCT Measurement of Femoral Diaphysis

\begin{tabular}{|c|c|c|c|c|c|c|c|}
\hline \multirow[b]{2}{*}{ Parameter } & \multicolumn{2}{|l|}{ Jak1 $1^{\text {S645P+/+ }}$} & \multicolumn{2}{|l|}{ Jak1 ${ }^{\text {S645P+/- }}$} & \multicolumn{2}{|c|}{ WT:mut $P$ value } & \multirow{2}{*}{$\begin{array}{l}\text { ANOVA } P \text { value } \\
\text { (genotype:sex } \\
\text { ratio) }\end{array}$} \\
\hline & Female $(n=9)$ & Male $(n=12)$ & Female $(n=5)$ & Male $(n=11)$ & Female & Male & \\
\hline Total density $\left(\mathrm{mg} / \mathrm{cm}^{3}\right)$ & $1117 \pm 41$ & $1042 \pm 40$ & $855 \pm 60$ & $809 \pm 90$ & $<0.001$ & $<0.001$ & \\
\hline Trabecular density $\left(\mathrm{mg} / \mathrm{cm}^{3}\right)$ & $212 \pm 34$ & $201 \pm 28$ & $170 \pm 17$ & $174 \pm 22$ & $<0.05$ & $<0.05$ & \\
\hline Cortical density $\left(\mathrm{mg} / \mathrm{cm}^{3}\right)$ & $1235 \pm 17$ & $1179 \pm 24$ & $1095 \pm 40$ & $1031 \pm 62$ & $<0.001$ & $<0.001$ & \\
\hline Total content $(\mathrm{mg})$ & $2.67 \pm 0.20$ & $2.57 \pm 0.14$ & $1.89 \pm 0.32$ & $1.65 \pm 0.44$ & $<0.001$ & $<0.001$ & \\
\hline Trabecular content (mg) & $0.06 \pm 0.01$ & $0.07 \pm 0.02$ & $0.10 \pm 0.02$ & $0.09 \pm 0.02$ & $<0.001$ & $<0.05$ & $<0.05$ \\
\hline Cortical content (mg) & $2.62 \pm 0.21$ & $2.50 \pm 0.14$ & $1.80 \pm 0.31$ & $1.56 \pm 0.43$ & $<0.001$ & $<0.001$ & \\
\hline Total area $\left(\mathrm{mm}^{2}\right)$ & $2.39 \pm 0.14$ & $2.47 \pm 0.12$ & $2.20 \pm 0.25$ & $2.01 \pm 0.30$ & & $<0.001$ & \\
\hline Trabecular area $\left(\mathrm{mm}^{2}\right)$ & $0.27 \pm 0.06$ & $0.35 \pm 0.07$ & $0.57 \pm 0.09$ & $0.51 \pm 0.08$ & $<0.001$ & $<0.001$ & $<0.05$ \\
\hline Cortical area $\left(\mathrm{mm}^{2}\right)$ & $2.12 \pm 0.15$ & $2.12 \pm 0.10$ & $1.63 \pm 0.22$ & $1.49 \pm 0.31$ & $<0.001$ & $<0.001$ & \\
\hline Periosteal circumference $(\mathrm{mm})$ & $5.48 \pm 0.16$ & $5.57 \pm 0.13$ & $5.25 \pm 0.29$ & $5.01 \pm 0.36$ & & $<0.001$ & \\
\hline Endosteal circumference (mm) & $2.18 \pm 0.19$ & $2.41 \pm 0.18$ & $2.87 \pm 0.18$ & $2.76 \pm 0.18$ & $<0.001$ & $<0.001$ & $<0.05$ \\
\hline
\end{tabular}

Data are presented as means \pm SEM.

ANOVA, analysis of variance; mut, mutant. 
bodies. Consistent with this observation, Jakl $1^{\mathrm{S645P+/-}}$ mice showed significantly increased levels of immunoglobulins in the circulation. We speculate that, because of the activating mutation in Jakl, the spleen B cells are more susceptible to IL-6 and, therefore, react with a moderate increase in B-cell differentiation to plasma cells. ${ }^{67} \mathrm{~B}$ cells in patients with SLE were reported to produce IL- 6 and respond to IL-6, leading to enhanced production of immunoglobulins. ${ }^{67,68}$ In aged lupus MRL/lrp mice, increased serum levels of IL-6 were determined, ${ }^{69}$ and in aged lupus NZBxNZB mice, IL-6 was reported to enhance the $\mathrm{IgG}$ anti-DNA antibody production by splenic B cells. ${ }^{70}$

Analysis of the frequencies of leukocyte subpopulations in peripheral blood revealed an increased frequency of $\mathrm{CD} 8^{+} \mathrm{T}$ cells positive for the differentiation marker, Ly-6C. The $\mathrm{CD}^{+} \mathrm{T}$-cell specificity might partly be explained by the fact that $\mathrm{Ly}-6 \mathrm{C}$ is not found on $\mathrm{CD} 4^{+} \mathrm{T}$ cells in Ly-6.1 background strains. ${ }^{71}$ Because Ly- $6 \mathrm{C}$ has been reported to be up-regulated after exposure to IFN $\alpha,{ }^{72}$ it is tempting to speculate that elevated levels of IFN $\alpha$, as determined in patients with SLE, could be responsible for up-regulation of Ly-C6 in Jakl ${ }^{5645 P+/-}$ mice. The relationship between increased Ly-6C on T cells for SLE has to be further elucidated. Further analysis of cultivated peripheral blood cells revealed a higher expression of CD71 and CD69 $9^{39,40}$ on $\mathrm{T}$ cells and nonlymphocytes of $\mathrm{Jakl}^{\mathrm{S645P+/-}}$ mice, suggesting an increased activation status of immune cells in Jakl $1^{S 645 P+/-}$ mice. Thrombocytopenia has been associated with a severe familiar phenotype of SLE, ${ }^{73}$ postulating autoreactive antibodies against platelets. In $\mathrm{Jakl}^{\mathrm{S645P+/-}}$ mice, fewer megakaryocytes were determined, which correlated with reduced frequencies of platelets in the periphery in aged mutants. In addition, in this study, microcytic and hypochromic red blood cell counts, with increased anisocytosis, were measured, indicating irregular hematopoiesis. SLE was associated with hemolytic anemia, in some patients starting before other clinical symptoms. ${ }^{74}$

Interestingly, hypophosphatemia has been reported for juvenile patients with SLE, indicating that decreased $\mathrm{P}_{\mathrm{i}}$ levels are associated with disease activity. ${ }^{75}$ Hypophosphatemia with hypercalcemia was recently published in one case report on juvenile SLE. ${ }^{76}$ It is still unclear whether the hypophosphatemia in $\mathrm{Jakl}^{\mathrm{S645P+/}-}$ mice arose from primary or secondary effects, but the strong phenotype was consistently found in both young and old $\mathrm{Jakl}^{S 645 \mathrm{P+} /-}$ mice. In addition, we found significantly decreased levels of PTH and FGF23 in $\mathrm{Jakl} 1^{\mathrm{S645P+l-}}$ mice. FGF23 is the key regulator of phosphate homeostasis and acts as a phosphaturic hormone. It is an inhibitor of renal phosphate reabsorption and regulates the phosphate levels via enhanced excretion of $\mathrm{P}_{\mathrm{i}}$ through the kidney in hyperphosphatemic conditions. ${ }^{77}$ Despite strong hypophosphatemia, no renal phosphaturia could be found in Jakl $1^{S 645 P+/-}$ mice. Because FGF23 is directly regulated by the phosphate level in the serum, ${ }^{78}$ we assume that the low FGF23 level in Jak1 $1^{S 645 P+/-}$ mice is caused by the low phosphate level itself.
Because osteoporosis was also reported for patients with SLE, ${ }^{79}$ the elevated ALP activities may derive from the bone ALP isoform. To elucidate this observation, we measured the bone resorption marker, CTX-1, and found significantly increased values in $\mathrm{Jakl}^{\mathrm{S645 \textrm {P } + /}}$ mice, indicating that $\mathrm{Jakl}^{\mathrm{S} 645 \mathrm{P}+/-}$ mice have an impaired bone metabolism associated with increased bone resorption. Indeed, Jakl ${ }^{S 645 P+/-}$ mice showed reduced morphometric bone parameters, confirming a strong osteopenic phenotype. It is well known that several inflammatory diseases, such as rheumatoid arthritis, SLE, or inflammatory bowel disease, have been associated with bone resorption. ${ }^{80}$ Increased osteoclastogenesis and bone resorption were reported to be induced by IL-6 and IL-11 activating the gp-130-JAK1-STAT3 axis, whereas IL-6 was shown to inhibit bone formation. ${ }^{81-83}$ Also worth mentioning is that IL-6-type cytokines stimulated ALP activity, which could explain the elevated levels of ALP observed in the $\mathrm{Jakl}^{\mathrm{S645P+/}-}$ mice. ${ }^{84}$ Although the causative key mechanism is still unknown, it can be summarized that the clear osteopenic phenotype found in $\mathrm{Jakl}^{\mathrm{S645P+/-}}$ mice is consistent with observations made in patients with SLE and has not been described in equivalent high degrees in other SLE mouse models.

According to the American Rheumatism Association for diagnosis of SLE, $\mathrm{Jakl}^{\mathrm{S} 645 \mathrm{P+} /-}$ mice fulfill at least four of the eleven diagnostic criteria required for disease classification, which are inflammatory severe lesions in skin and ears, hypergammaglobulinemia and highly elevated levels of anti-DNA antibodies, NRH of the liver, splenomegaly, and thrombocytopenia. In addition to the American Rheumatism Association criteria, IL-6 and dysregulation of the JAK/STAT pathway are regarded as critical factors in SLE pathogenesis. ${ }^{54,85}$ In addition, increased IL-6 levels have been reported to induce development of the SLE-like phenotype in murine models. ${ }^{34,69,70}$ The clinical outcome of SLE often is diverse, as it was described for human triplets with SLE carrying the identical mutation, ${ }^{86}$ and not every of the existing mouse models is showing all LE criteria. ${ }^{87}$ Thus, the development of all SLE criteria may be due to multigenetic effects.

In conclusion, the new ENU mutagenesis-derived point mutation leading to the $\mathrm{Jakl}^{\mathrm{S645P+/-}}$ mouse line induces multiple phenotypes of systemic autoimmune diseases, such as SLE. This mouse line may serve as a useful in vivo model for further analysis of pathophysiological features and therapies for autoimmune diseases. Because several companies are in late-stage clinical programs for the development of JAK kinase inhibitors to treat arthritis, psoriasis, lupus, colitis, and multiple types of cancer, $\mathrm{Jakl}^{\mathrm{S645P+/-}}$ mice may serve as a model for new therapeutic strategies. ${ }^{41,88}$

\section{Acknowledgments}

We thank Sandra Hoffmann, Andreas Mayer, Elenore Samson, Lucie Thurmann, Jacqueline Müller, Sandy 
Lösecke, Elfi Holupirek, Tommy Fuchs, Silvia Crowley, and Gerlinde Bergter for excellent technical assistance; Christine Gau for statistical analysis; Dr. Jan Gutermuth for preliminary real-time PCR analysis; and Shen Chi and Davide Cavanna for real-time PCR analysis of ear tissues.

\section{Supplemental Data}

Supplemental material for this article can be found at http://dx.doi.org/10.1016/j.ajpath.2013.04.027.

\section{References}

1. Sigurdsson S, Nordmark G, Goring HH, Lindroos K, Wiman AC, Sturfelt G, Jonsen A, Rantapaa-Dahlqvist S, Moller B, Kere J, Koskenmies S, Widen E, Eloranta ML, Julkunen H, Kristjansdottir H, Steinsson K, Alm G, Ronnblom L, Syvanen AC: Polymorphisms in the tyrosine kinase 2 and interferon regulatory factor 5 genes are associated with systemic lupus erythematosus. Am J Hum Genet 2005, 76:528-537

2. Goris A, Liston A: The immunogenetic architecture of autoimmune disease. Cold Spring Harb Perspect Biol 2012, 4. pii: a007260

3. Furukawa F, Kanauchi H, Wakita H, Tokura Y, Tachibana T, Horiguchi Y, Imamura S, Ozaki S, Takigawa M: Spontaneous autoimmune skin lesions of MRL/n mice: autoimmune disease-prone genetic background in relation to Fas-defect MRL/1pr mice. J Invest Dermatol 1996, 107:95-100

4. Morel L, Mohan C, Yu Y, Croker BP, Tian N, Deng A, Wakeland EK: Functional dissection of systemic lupus erythematosus using congenic mouse strains. J Immunol 1997, 158:6019-6028

5. Reeves WH, Lee PY, Weinstein JS, Satoh M, Lu L: Induction of autoimmunity by pristane and other naturally occurring hydrocarbons. Trends Immunol 2009, 30:455-464

6. Bosma GC, Custer RP, Bosma MJ: A severe combined immunodeficiency mutation in the mouse. Nature 1983, 301:527-530

7. Green MC, Shultz LD: Motheaten, an immunodeficient mutant of the mouse, I: genetics and pathology. J Hered 1975, 66:250-258

8. Massironi SM, Dagli ML, Lima MR, Alvarez JM, Kipnis TL: A new mutant hairless mouse with lymph node hyperplasia and late onset of autoimmune pathology. Braz J Med Biol Res 1994, 27:2401-2405

9. Grosse J, Chitu V, Marquardt A, Hanke P, Schmittwolf C, Zeitlmann L, Schropp P, Barth B, Yu P, Paffenholz R, Stumm G, Nehls M, Stanley ER: Mutation of mouse Mayp/Pstpip2 causes a macrophage autoinflammatory disease. Blood 2006, 107: 3350-3358

10. Alli R, Nguyen P, Boyd K, Sundberg JP, Geiger TL: A mouse model of clonal CD8 + T lymphocyte-mediated alopecia areata progressing to alopecia universalis. J Immunol 2012, 188:477-486

11. Harris JE, Harris TH, Weninger W, Wherry EJ, Hunter CA, Turka LA: A mouse model of vitiligo with focused epidermal depigmentation requires IFN- $\gamma$ for autoreactive $\mathrm{CD} 8^{+}$T-cell accumulation in the skin. J Invest Dermatol 2012, 132:1869-1876

12. Kasperkiewicz M, Nimmerjahn F, Wende S, Hirose M, Iwata H, Jonkman MF, Samavedam U, Gupta Y, Möller S, Rentz E, Hellberg L, Kalies K, Yu X, Schmidt E, Häsler R, Laskay T, Westermann J, Köhl J, Zillikens D, Ludwig RJ: Genetic identification and functional validation of FcrRIV as key molecule in autoantibody-induced tissue injury. J Pathol 2012, 228:8-19

13. Haan C, Kreis S, Margue C, Behrmann I: Jaks and cytokine receptors: an intimate relationship. Biochem Pharmacol 2006, 72:1538-1546

14. Murray PJ: The JAK-STAT signaling pathway: input and output integration. J Immunol 2007, 178:2623-2629

15. Hornakova T, Chiaretti S, Lemaire MM, Foa R, Ben Abdelali R, Asnafi V, Tartaglia M, Renauld JC, Knoops L: ALL-associated JAK1 mutations confer hypersensitivity to the antiproliferative effect of type I interferon. Blood 2010, 115:3287-3295

16. Hornakova T, Springuel L, Devreux J, Dusa A, Constantinescu SN Knoops L, Renauld JC: Oncogenic JAK1 and JAK2-activating mutations resistant to ATP-competitive inhibitors. Haematologica 2011, 96:845-853

17. Vainchenker W, Dusa A, Constantinescu SN: JAKs in pathology: role of Janus kinases in hematopoietic malignancies and immunodeficiencies. Semin Cell Dev Biol 2008, 19:385-393

18. Sabrautzki S, Rubio-Aliaga I, Hans W, Fuchs H, Rathkolb B, Calzada-Wack J, Cohrs CM, Klaften M, Seedorf H, Eck S, BenetPagès A, Favor J, Esposito I, Strom TM, Wolf E, LorenzDepiereux B, Hrabě de Angelis M: New mouse models for metabolic bone diseases generated by genome-wide ENU mutagenesis. Mamm Genome 2012, 23:416-430

19. Hrabe de Angelis MH, Flaswinkel H, Fuchs H, Rathkolb B, Soewarto D, Marschall S, et al: Genome-wide, large-scale production of mutant mice by ENU mutagenesis. Nat Genet 2000, 25:444-447

20. Aigner B, Rathkolb B, Klempt M, Wagner S, Michel D, Klaften M, Laufs J, Schneider B, Sedlmeier R, Hrabe de Angelis M, Wolf E: Generation of N-ethyl-N-nitrosourea-induced mouse mutants with deviations in hematological parameters. Mamm Genome 2011, 22: 495-505

21. Nicklas W, Baneux P, Boot R, Decelle T, Deeny AA, Fumanelli M, Illgen-Wilcke $\mathrm{B}$ : Recommendations for the health monitoring of rodent and rabbit colonies in breeding and experimental units. Lab Anim 2002, 36:20-42

22. Fuchs H, Gailus-Durner V, Neschen S, Adler T, Afonso LC, AguilarPimentel JA, et al: Innovations in phenotyping of mouse models in the German Mouse Clinic. Mamm Genome 2012, 23:611-622

23. Gailus-Durner V, Fuchs H, Becker L, Bolle I, Brielmeier M, CalzadaWack J, et al: Introducing the German Mouse Clinic: open access platform for standardized phenotyping. Nat Methods 2005, 2: 403-404

24. Staropoli JF, Haliw L, Biswas S, Garrett L, Holter SM, Becker L, et al: Large-scale phenotyping of an accurate genetic mouse model of JNCL identifies novel early pathology outside the central nervous system. PLoS One 2012, 7:e38310

25. Gömöri G: Silver impregnation of reticulum in paraffin sections. Am J Pathol 1937, 13:993-1002.5

26. Ateghang B, Wartenberg M, Gassmann M, Sauer H: Regulation of cardiotrophin-1 expression in mouse embryonic stem cells by HIF1alpha and intracellular reactive oxygen species. J Cell Sci 2006, 119:1043-1052

27. Rathkolb B, Decker T, Fuchs E, Soewarto D, Fella C, Heffner S, Pargent W, Wanke R, Balling R, Hrabe de Angelis M, Kolb HJ, Wolf E: The clinical-chemical screen in the Munich ENU Mouse Mutagenesis Project: screening for clinically relevant phenotypes. Mamm Genome 2000, 11:543-546

28. Klempt M, Rathkolb B, Fuchs E, de Angelis MH, Wolf E, Aigner B: Genotype-specific environmental impact on the variance of blood values in inbred and F1 hybrid mice. Mamm Genome 2006, 17: 93-102

29. Roederer M, Nozzi JL, Nason MC: SPICE: exploration and analysis of post-cytometric complex multivariate datasets. Cytometry A 2011, 79:167-174

30. Klaften M, Hrabe de Angelis M: ARTS: a web-based tool for the setup of high-throughput genome-wide mapping panels for the SNP genotyping of mouse mutants. Nucleic Acids Res 2005, 33: W496-W500

31. Eck SH, Benet-Pages A, Flisikowski K, Meitinger T, Fries R, Strom TM: Whole genome sequencing of a single Bos taurus animal for single nucleotide polymorphism discovery. Genome Biol 2009, 10:R82

32. Li H, Ruan J, Durbin R: Mapping short DNA sequencing reads and calling variants using mapping quality scores. Genome Res 2008 , 18 : $1851-1858$ 
33. Ichiba M, Nakajima K, Yamanaka Y, Kiuchi N, Hirano T: Autoregulation of the Stat3 gene through cooperation with a cAMPresponsive element-binding protein. J Biol Chem 1998, 273: 6132-6138

34. Pflegerl P, Vesely P, Hantusch B, Schlederer M, Zenz R, Janig E, Steiner G, Meixner A, Petzelbauer P, Wolf P, Soleiman A, Egger G, Moriggl R, Kishimoto T, Wagner EF, Kenner L: Epidermal loss of JunB leads to a SLE phenotype due to hyper IL-6 signaling. Proc Natl Acad Sci U S A 2009, 106:20423-20428

35. Guschin D, Rogers N, Briscoe J, Witthuhn B, Watling D, Horn F, Pellegrini S, Yasukawa K, Heinrich P, Stark GR: A major role for the protein tyrosine kinase JAK1 in the JAK/STAT signal transduction pathway in response to interleukin-6. EMBO J 1995, 14:1421-1429

36. Gibson RM, Schiemann WP, Prichard LB, Reno JM, Ericsson LH, Nathanson NM: Phosphorylation of human gp130 at Ser-782 adjacent to the Di-leucine internalization motif: effects on expression and signaling. J Biol Chem 2000, 275:22574-22582

37. Murakami M, Hibi M, Nakagawa N, Nakagawa T, Yasukawa K, Yamanishi K, Taga T, Kishimoto T: IL-6-induced homodimerization of gp130 and associated activation of a tyrosine kinase. Science 1993, 260:1808-1810

38. Hartleb M, Gutkowski K, Milkiewicz P: Nodular regenerative hyperplasia: evolving concepts on underdiagnosed cause of portal hypertension. World J Gastroenterol 2011, 17:1400-1409

39. Teixeira S, Kuhn LC: Post-transcriptional regulation of the transferrin receptor and 4F2 antigen heavy chain mRNA during growth activation of spleen cells. Eur J Biochem 1991, 202:819-826

40. Ziegler SF, Ramsdell F, Alderson MR: The activation antigen CD69. Stem Cells 1994, 12:456-465

41. Seavey MM, Dobrzanski P: The many faces of Janus kinase. Biochem Pharmacol 2012, 83:1136-1145

42. Flex E, Petrangeli V, Stella L, Chiaretti S, Hornakova T, Knoops L, Ariola C, Fodale V, Clappier E, Paoloni F, Martinelli S, Fragale A, Sanchez M, Tavolaro S, Messina M, Cazzaniga G, Camera A, Pizzolo G, Tornesello A, Vignetti M, Battistini A, Cave H, Gelb BD, Renauld JC, Biondi A, Constantinescu SN, Foa R, Tartaglia M: Somatically acquired JAK1 mutations in adult acute lymphoblastic leukemia. J Exp Med 2008, 205:751-758

43. James C, Ugo V, Le Couedic JP, Staerk J, Delhommeau F, Lacout C, Garcon L, Raslova H, Berger R, Bennaceur-Griscelli A, Villeval JL, Constantinescu SN, Casadevall N, Vainchenker W: A unique clonal JAK2 mutation leading to constitutive signalling causes polycythaemia vera. Nature 2005, 434:1144-1148

44. Kralovics R, Teo SS, Buser AS, Brutsche M, Tiedt R, Tichelli A, Passamonti F, Pietra D, Cazzola M, Skoda RC: Altered gene expression in myeloproliferative disorders correlates with activation of signaling by the V617F mutation of Jak2. Blood 2005, 106: 3374-3376

45. Levine RL, Gilliland DG: JAK-2 mutations and their relevance to myeloproliferative disease. Curr Opin Hematol 2007, 14:43-47

46. Mullighan CG, Zhang J, Harvey RC, Collins-Underwood JR, Schulman BA, Phillips LA, Tasian SK, Loh ML, Su X, Liu W, Devidas M, Atlas SR, Chen IM, Clifford RJ, Gerhard DS, Carroll WL, Reaman GH, Smith M, Downing JR, Hunger SP, Willman CL: JAK mutations in high-risk childhood acute lymphoblastic leukemia. Proc Natl Acad Sci U S A 2009, 106:9414-9418

47. Rodig SJ, Meraz MA, White JM, Lampe PA, Riley JK, Arthur CD, King KL, Sheehan KC, Yin L, Pennica D, Johnson EM Jr, Schreiber RD: Disruption of the Jak1 gene demonstrates obligatory and nonredundant roles of the Jaks in cytokine-induced biologic responses. Cell 1998, 93:373-383

48. Perry D, Sang A, Yin Y, Zheng YY, Morel L: Murine models of systemic lupus erythematosus. J Biomed Biotechnol 2011, 2011: 271694

49. Furukawa F, Yoshimasu T: Animal models of spontaneous and druginduced cutaneous lupus erythematosus. Autoimmun Rev 2005, 4: $345-350$
50. Fiegel F, Buhl A, Jaekel HP, Werle E, Schmolke M, Ollert M, Luppa PB: Autoantibodies to double-stranded DNA: intermethod comparison between four commercial immunoassays and a research biosensor-based device. Lupus 2010, 19:957-964

51. Renau AI, Isenberg DA: Male versus female lupus: a comparison of ethnicity, clinical features, serology and outcome over a 30 year period. Lupus 2012, 21:1041-1048

52. Cash H, Relle M, Menke J, Brochhausen C, Jones SA, Topley N, Galle PR, Schwarting A: Interleukin 6 (IL-6) deficiency delays lupus nephritis in MRL-Faslpr mice: the IL-6 pathway as a new therapeutic target in treatment of autoimmune kidney disease in systemic lupus erythematosus. J Rheumatol 2010, 37:60-70

53. Jacob N, Stohl W: Cytokine disturbances in systemic lupus erythematosus. Arthritis Res Ther 2011, 13:228

54. Smolen JS, Steiner G, Aringer M: Anti-cytokine therapy in systemic lupus erythematosus. Lupus 2005, 14:189-191

55. Hooks JJ, Moutsopoulos HM, Geis SA, Stahl NI, Decker JL, Notkins AL: Immune interferon in the circulation of patients with autoimmune disease. N Engl J Med 1979, 301:5-8

56. Shi SN, Feng SF, Wen YM, He LF, Huang YX: Serum interferon in systemic lupus erythematosus. Br J Dermatol 1987, 117:155-159

57. Nacionales DC, Kelly-Scumpia KM, Lee PY, Weinstein JS, Lyons R, Sobel E, Satoh M, Reeves WH: Deficiency of the type I interferon receptor protects mice from experimental lupus. Arthritis Rheum 2007, 56:3770-3783

58. Ramirez-Velez G, Medina F, Ramirez-Montano L, ZarazuaLozada A, Hernandez R, Llorente L, Moreno J: Constitutive phosphorylation of interferon receptor A-associated signaling proteins in systemic lupus erythematosus. PLoS One 2012, 7:e41414

59. Leung VK, Ng WL, Luk IS, Chau TN, Chan WH, Kei SK, Loke TK: Unique hepatic imaging features in a patient with nodular regenerative hyperplasia of the liver associating with systemic lupus erythematosus. Lupus 2007, 16:205-208

60. Vaiphei K, Bhatia A, Sinha SK: Liver pathology in collagen vascular disorders highlighting the vascular changes within portal tracts. Indian J Pathol Microbiol 2011, 54:25-31

61. Matsumoto T, Kobayashi S, Shimizu H, Nakajima M, Watanabe S, Kitami N, Sato N, Abe H, Aoki Y, Hoshi T, Hashimoto H: The liver in collagen diseases: pathologic study of 160 cases with particular reference to hepatic arteritis, primary biliary cirrhosis, autoimmune hepatitis and nodular regenerative hyperplasia of the liver. Liver 2000, 20:366-373

62. Matsumoto T, Yoshimine T, Shimouchi K, Shiotu H, Kuwabara N, Fukuda Y, Hoshi T: The liver in systemic lupus erythematosus: pathologic analysis of 52 cases and review of Japanese Autopsy Registry Data. Hum Pathol 1992, 23:1151-1158

63. Klemp P, Timme AH, Sayers GM: Systemic lupus erythematosus and nodular regenerative hyperplasia of the liver. Ann Rheum Dis 1986, 45:167-170

64. Maione D, Di Carlo E, Li W, Musiani P, Modesti A, Peters M, RoseJohn S, Della Rocca C, Tripodi M, Lazzaro D, Taub R, Savino R, Ciliberto G: Coexpression of IL-6 and soluble IL-6R causes nodular regenerative hyperplasia and adenomas of the liver. EMBO J 1998, 17:5588-5597

65. Kunder S, Calzada-Wack J, Holzlwimmer G, Muller J, Kloss C, Howat W, Schmidt J, Hofler H, Warren M, Quintanilla-Martinez L: A comprehensive antibody panel for immunohistochemical analysis of formalin-fixed, paraffin-embedded hematopoietic neoplasms of mice: analysis of mouse specific and human antibodies cross-reactive with murine tissue. Toxicol Pathol 2007, 35:366-375

66. Morse HC 3rd, Anver MR, Fredrickson TN, Haines DC, Harris AW, Harris NL, Jaffe ES, Kogan SC, MacLennan IC, Pattengale PK, Ward JM: Bethesda proposals for classification of lymphoid neoplasms in mice. Blood 2002, 100:246-258

67. Tanaka Y, Saito K, Shirakawa F, Ota T, Suzuki H, Eto S, Yamashita U: Production of B cell-stimulating factors by B cells in patients with systemic lupus erythematosus. J Immunol 1988, 141:3043-3049 
68. Klashman DJ, Martin RA, Martínez-Maza O, Stevens RH: In vitro regulation of B cell differentiation by interleukin- 6 and soluble CD23 in systemic lupus erythematosus B cell subpopulations and antigeninduced normal B cells. Arthritis Rheum 1991, 34:276-286

69. Tang B, Matsuda T, Akira S, Nagata N, Ikehara S, Hirano T, Kishimoto T: Age-associated increase in interleukin 6 in MRL/lpr mice. Int Immunol 1991, 3:273-278

70. Kanno K, Okada T, Abe M, Hirose S, Shirai T: Differential sensitivity to interleukins of CD5+ and CD5-anti-DNA antibodyproducing B cells in murine lupus. Autoimmunity 1993, 14:205-214

71. Schlueter AJ, Malek TR, Hostetler CN, Smith PA, deVries P, Waldschmidt TJ: Distribution of Ly-6C on lymphocyte subsets, I: influence of allotype on T lymphocyte expression. J Immunol 1997, 158:4211-4222

72. Schlueter AJ, Krieg AM, de Vries P, Li X: Type I interferon is the primary regulator of inducible Ly-6C expression on T cells. J Interferon Cytokine Res 2001, 21:621-629

73. Scofield RH, Bruner GR, Kelly JA, Kilpatrick J, Bacino D, Nath SK, Harley JB: Thrombocytopenia identifies a severe familial phenotype of systemic lupus erythematosus and reveals genetic linkages at 1q22 and 11p13. Blood 2003, 101:992-997

74. Kelly JA, Thompson K, Kilpatrick J, Lam T, Nath SK, GrayMcGuire C, Reid J, Namjou B, Aston CE, Bruner GR, Scofield RH, Harley JB: Evidence for a susceptibility gene (SLEH1) on chromosome 11q14 for systemic lupus erythematosus (SLE) families with hemolytic anemia. Proc Natl Acad Sci U S A 2002, 99:11766-11771

75. Fujiwara I, Ogawa E, Kondo Y, Ohura T, Iinuma K: Hypophosphatemia in juvenile patients with systemic lupus erythematosus. Pediatr Int 2003, 45:23-30

76. Kohli U, Lodha R, Bagga A: Familial systemic lupus erythematosus with hypercalcemia. Indian J Pediatr 2008, 75:855-857
77. Digirolamo DJ, Clemens TL, Kousteni S: The skeleton as an endocrine organ. Nat Rev Rheumatol 2012, 8:674-683

78. Haussler MR, Jurutka PW, Mizwicki M, Norman AW: Vitamin D receptor (VDR)-mediated actions of 1alpha,25(OH)(2)vitamin $\mathrm{D}(3)$ : genomic and non-genomic mechanisms. Best Pract Res Clin Endocrinol Metab 2011, 25:543-559

79. Bultink IE: Osteoporosis and fractures in systemic lupus erythematosus. Arthritis Care Res (Hoboken) 2012, 64:2-8

80. Braun T, Schett G: Pathways for bone loss in inflammatory disease. Curr Osteoporos Rep 2012, 10:101-108

81. Heymann D, Rousselle AV: gp130 Cytokine family and bone cells. Cytokine 2000, 12:1455-1468

82. Hughes FJ, Howells GL: Interleukin-6 inhibits bone formation in vitro. Bone Miner 1993, 21:21-28

83. Kudo O, Sabokbar A, Pocock A, Itonaga I, Fujikawa Y, Athanasou NA: Interleukin-6 and interleukin-11 support human osteoclast formation by a RANKL-independent mechanism. Bone 2003, 32:1-7

84. Bellido T, Borba VZ, Roberson P, Manolagas SC: Activation of the Janus kinase/STAT (signal transducer and activator of transcription) signal transduction pathway by interleukin-6-type cytokines promotes osteoblast differentiation. Endocrinology 1997, 138:3666-3676

85. Chun HY, Chung JW, Kim HA, Yun JM, Jeon JY, Ye YM, Kim SH, Park HS, Suh CH: Cytokine IL-6 and IL-10 as biomarkers in systemic lupus erythematosus. J Clin Immunol 2007, 27:461-466

86. Kamat SS, Pepmueller PH, Moore TL: Triplets with systemic lupus erythematosus. Arthritis Rheum 2003, 48:3176-3180

87. Seavey MM, Lu LD, Stump KL: Animal models of systemic lupus erythematosus (SLE) and ex vivo assay design for drug discovery. Curr Protoc Pharmacol 2011. Chapter 5:Unit 5.60

88. Tsokos GC: Systemic lupus erythematosus. N Engl J Med 2011, 365: 2110-2121 